\title{
GEOTHERMAL DEVELOPMENT PLAN: PIMA COUNTY
}

\author{
by
}

The Arizona Geothermal Commercialization Team

Don H. White, Ph.D., Principal Investigator

Larry A. Goldstone, Project Manager

Arizona Geological Survey

Open-File Report 79-9

\section{Arizona Geological Survey}

416 W. Congress, Suite \#100, Tucson, Arizona 85701

State Contractor:

Arizona Solar Energy Commission

James $F$. Warnock, Jr, Director

Frank Mancini, Ph.D., Associate Director

1700 West Washington Phoenix, Arizona 85007

Work performed under

Contract No. DE-FC03-80RA50076

Modification No. A-001 Evaluation of Geothermal Energy in Arizona

U.S. Department of Energy San Francisco Office Region IX

Subcontract 114-80 with Department of Chemical Engineering

This report is preliminary and has not been edited or reviewed for conformity with Arizona Geological Survey standards 



\section{ACRNOWLEDGEMENTS}

The Arizona Geothermal Commercialization Team has been comprised of many individuals over the past several years. Recognition is extended to the following professors who have contributed to the Team's efforts: John Kessler, Ph.D.; Mike Pasqualetti, Ph.D.; and David Wolf, Ph.D.

Group leaders were Mohamad Chehab, Larrg Goldscone, Lani Malysa and Bill Weibel.

Other contributors include Cherff Ballamane, Ronda Bitterli, Wei-hsin (Alex) Chung, Elizabeth Foster, Jeff Hagen, Akram Hasan, Greta Jensen, Gary Kyle, Timeral Rowe, Edward Seames and John Westover.

The following people were special task contributors: Don Astrom, Greta Jensen, Iftikhar Khan, Doug Linkhart, Lani Malysa, Mobin Qaheri, Xavier Suarez, Cbarles Tabet and Steve Dnguran.

In addition, W. Richard Bahman, Sr., Claudia Stone and Ifm Witcher of the Arizona Bureau of Geology and Mineral Technology-Geothermal Group deserve recognition for their contributions and assistance.

Special thanks are extended to Bette Eolt for drafting some of the figures and to Peggy Jackson and Lee DeYonghe for their assistance in typing the final manuscript. 
LIST OF FIGURES . . . . . . . . . . . . . . . . . Ii

LIST OF TABLES . . . . . . . . . . . . . . . . . . iii

INTRODUCTION . . . . . . . . . . . . . . . . . 1

AREA DEVELOPMENT PLANS ..................... . . 1

GEOTHERMAL RESOURCES .................. 3

ECONOMY ..............................

Population . . . . . . . . . . . . . . . . 6

Growth ......................... 8

Industry and Employment . . . . . . . . . . . . . 11

Income . . . . . . . . . . . . . . . . . . . 14

Other Economic Indicators . . . . . . . . . . . 14

LAND OWNERSHIP . . . . . . . . . . . . . . . 16

ENERGY USE

WATER ............................ 26

MATCHING GEOTHERMAL RESOURCES TO POTENTIAL USERS . . . . . . 29

Primary Copper . . . . . . . . . . . . . . . 34

Soft Drink Industry . . . . . . . . . . . . . . . 37

Ready-Mix Concrete Industry . . . . . . . . . . . 38

SUMMARY ...................... 38

APPENDIX A . . . . . . . . . . . . . . . . 39

APPENDIX B . . . . . . . . . . . . . . . . . 41

BIBLIOGRAPHY . . . . . . . . . . . . . 4 44 
LIST OF FIGURES

Figure $\quad$ Page

1 Area Development Plans for Arizona 2

2 Arizona's Proven, Potential and Inferred Resources 4

3 Population Projections for Pima County to 20209

4 Fastest Growing Areas of Tucson 10

5 Major Employment Sector Projections for Pina County 12

6 Other Employment Sector Projections for Pima County 13

7 Projections of Personal Income (1972 Dollars) for Pima County 15

8 Projections of Personal Per Capita Income (1972 Dollars) for Pima County

9 General Land Ownership Map for Pima County 17

10 Estimated Electric Power Sales by Month for 1979

11 Daily Load Curve for Tucson Electric Power Co., July 19, 1978

12 Peak Electric Load, 1973 - 197925

13 Estimated Natural Gas Sales by Month, 197927

14 Projected Alternatives for Water Use in Pima County 28

15 Projected Geothermal Heat On Iine Under Private Development 31

16 Projected Geothermal Heat on Line Under City Development 32 
Table

Page

1 Some Common Conversion Factors

2 Proven and Potential Reservoirs of Pima County of Less Than $1.2 \mathrm{~km}$ Depth

3 Inferred Intermediate to High Teriperature $\left(>90^{\circ} \mathrm{C}\right)$ Geothermal Reservoirs of Pima. County of Less Than $2.5 \mathrm{Km}$ Depth

4 Major Cities in Pima County and Their Populations 8

5 Land Ownership by Acres 16

6 Pima County Energy-Use Projections 18

$7 \quad$ Estimated Average Energy Prices by User Class, $1978 \quad 18$

8 Real Price Growth Rates 19

9 Energy Use by User Class, $1978 \quad 20$

10 Projected Distribution of Electricity Sales in Pima County 21

II Estimated Process Heat Energy Requirements for Selected Industries in Pima County

12 Barrels of Oil Replaced by Geothermal Energy Per Year Process Heat Market

13 Typical Process Heat Consumption in the Copper Industry 35

14 Aggregate Process Heat Requirements for Primary and Secondary Copper 
INTRODUCTION

Alternative sources of energy will have to be developed as the availability of traditional energy resources continues to diminish. Arizona is supplied with geothermal reserves which could potentially supplement the existing energy supplies. Consequently, planning efforts have concentrated on estimating the potential of geothermal energy utilization in Arizona and in providing information necessary for its prospective commercialization.

Geothermal commercialization plans were prepared for seven distinct intrastate subdivisions. The geothermal resource prospect and the potential geothermal uses for each area are discussed in separate Area Development Plans (ADPs). The major objective of the ADP is to provide information for the prospective development and commercialization of geothermal energy in the specified area. Attempts are made to match the available geothermal resources to potential residential, comercial, industrial and agricultural users.

Pima County is located entirely within the Basin and Range physiographic province in which geothermal resources are known to occur. Continued growth as indicated by such factors as population growth, employment and income will require large amounts of energy. It is believed that geothermal energy could provide some of the energy that will be needed. Potential users of geothermal energy within the county are identified. AREA DEVELOPMENT PLANS

Arfzona has been divided into seven distinct single or multicounty subdivisions for which Area Development Plans (ADPs) for geothermal commercialization have been developed. A map of Arizona presented in Figure 1 shows these areas which are numbered in order of planning priority. 


\section{Pelorties}

I) Marlcopa

II) PIma

III) Graham/Greenlee

IV) Pinal

V) Yuma

VI) Cochise/Santa Cruz

VII) Northern Counties

$(1,3,4,8,9,13)$

\section{County Names}

1. Apache

2. Cochise

3. Coconino

4. Gila

5. Graham

6. Greenlee

7. Maricopa

8. Mohave

9.- Navajo

10. Pima

11. Pinal

12. Santa Cruz

13. Yavapa1

14. Yuma

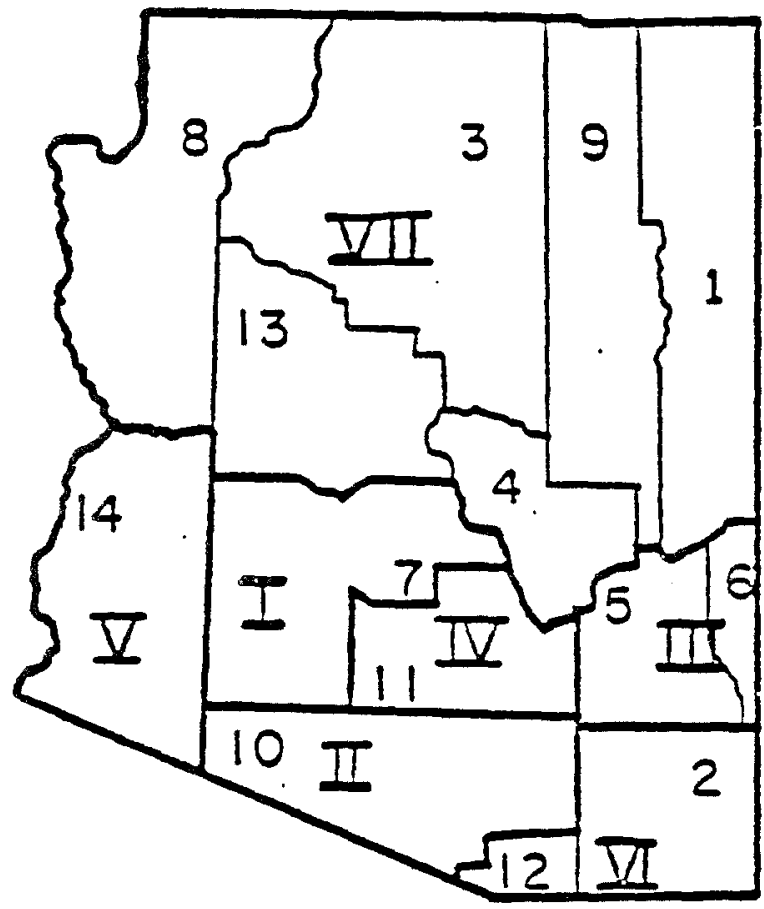

2

Figure 1: Area Development Plans for Arizona. 
This ADP is concerned with Pima County. Both metric and English units are provided in the text. However, only metric units appear in the tables and figures. For convenience, some common conversion factors are Iisted in Table 1. In this report, one million Btu = MBtu.

TABLE 1: SOME COMMON CONVERSION FACTORS

Length and Volume Conversions:

To Convert:

Multiply By:

To Obtain:

meters

3.281

feet

kilometers

0.6214

miles

cubic kilometers

0.2399

cubic miles

liters

0.2642

gallons

Temperature Conversions: ${ }^{\circ} F=\left(1.8 \times{ }^{\circ} \mathrm{C}\right)+32$

GEOTHERMAL RESOURCES

Pima County lies entirely within the Basin and Range physiographic province which is characterized by numerous mountain ranges arising abruptly from broad valleys. At least four areas known to store thermal water at relatively shallow depths of less than $1200 \mathrm{~m}$ (3940 ft) are located within Pima County. Numbered boxes in Figure 2 identify these areas; Table 2 gives the location of each of these areas along with rough estimates of depth, volume and temperature.

The Tucson merropolitan area is located in the Santa Cruz Valley, a broad, sediment-filled basin surrounded by mountains. A deep oil test well near the center of the basin had a bottom hole temperature of $147^{\circ} \mathrm{C}$ $\left(297^{\circ} \mathrm{F}\right)$ at a depth of $3600 \mathrm{~m}(11,810 \mathrm{ft})$. Flve miles northeast of the oil test well are water wells in which thermal water has been encountered. The higiest measured temperature was $32.2^{\circ} \mathrm{C}\left(126^{\circ} \mathrm{E}\right)$ ar a depth of 762 I (2500 EL). 


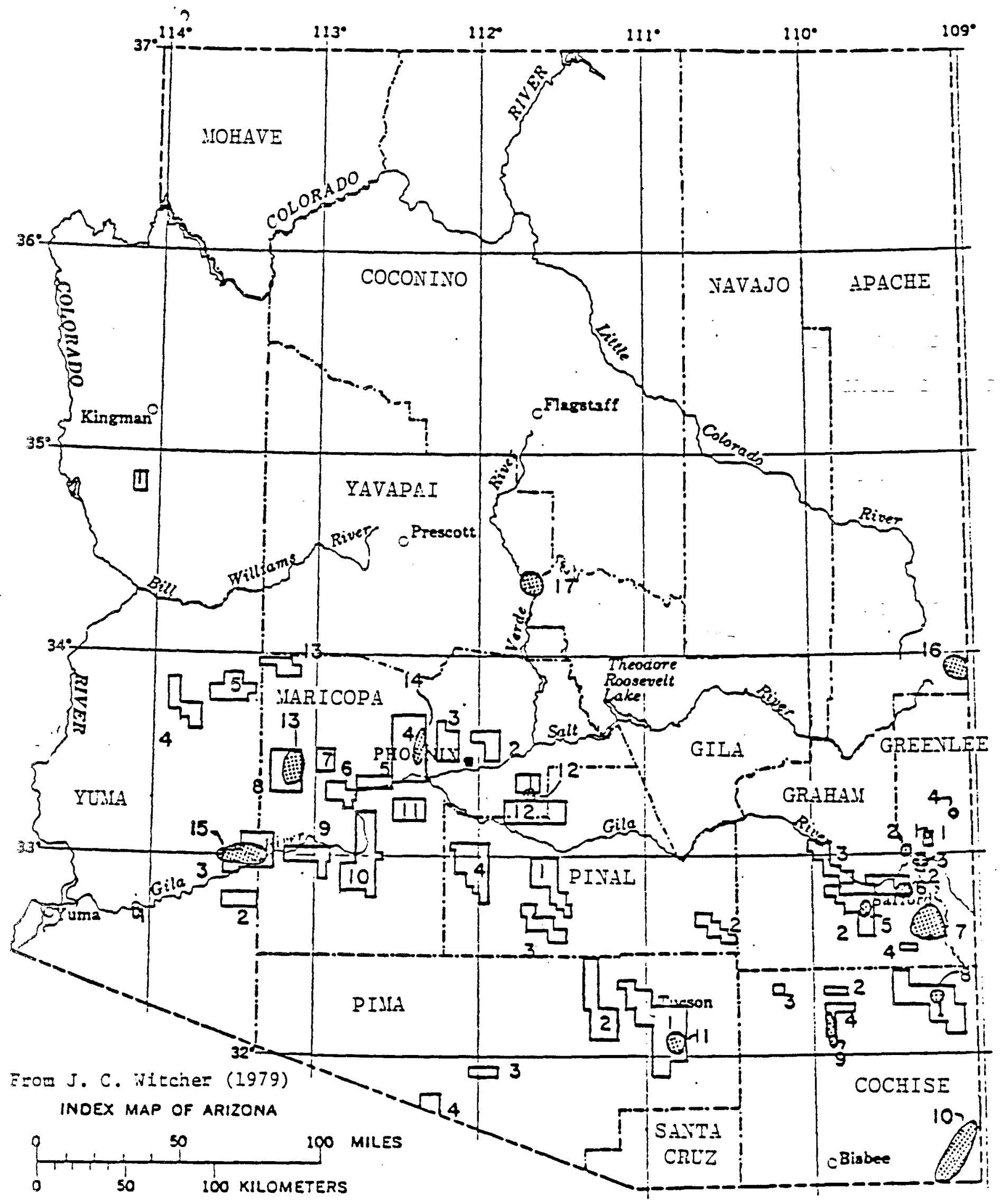




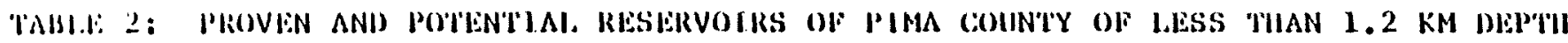
Modfifed from witelier (1979) Tr - Average Reservole l'emperature

\begin{tabular}{|c|c|c|c|c|c|c|c|}
\hline Ari:: & lat:atifon & $\begin{array}{l}\text { Volunge } \\
\text { (lou })\end{array}$ & $\begin{array}{l}\text { Mesalsured ("(:) } \\
\text { l'emperatiore }\end{array}$ & $\begin{array}{l}\text { Depth } \\
\text { (kiin) }\end{array}$ & $\operatorname{Ir}-{ }^{\circ} \mathrm{c}$ & $\begin{array}{l}\text { Geothermometry } \\
\text { lemperature of }\end{array}$ & Method \\
\hline 1 & $112-1 \%$, RI2-15i & 287.9 & $30-50$ & $<0.76$ & 60 & $50-65$ & Chalcedony, Na-K-Ca \\
\hline 2 & $112-155, \mathrm{R} 10-11 \mathrm{E}$ & 157.9 & $30-45$ & $<0.61$ & 60 & $30-60$ & Chalcedony \\
\hline 1 & IItS, R3-5k & 30.9 & $35-40$ & $<0.21$ & 55 & $50-60$ & Chalcedony \\
\hline 4 & I9-20s, R3lE & 40.3 & $30-45$ & $<0.30$ & 65 & $50-80$ & Chalcedony \\
\hline
\end{tabular}


Warm water from wells on the Papago Indian Reservation indicates the existence of low temperature $\left(<90^{\circ} \mathrm{C} ;<194^{\circ} \mathrm{F}\right)$ geothermal potential in $\mathrm{Pima}$ County. Much of the reservation is unexplored, but several water wells on the Papago Farms southwest of Sells have encountered $45^{\circ} \mathrm{C}$ ( $113^{\circ} \mathrm{F}$ ) to $47^{\circ} \mathrm{C}$ $\left(117^{\circ} \mathrm{F}\right)$ water at depths of less than $200 \mathrm{~m}$ (656 ft) (Stone, 1980). Intermediate temperature geothermal potential is inferred from presently available geological, geochemical and geophysical information (WItcher, 1979). The location of one inferred potential reservoir in Pima County and rough estimates of its depth, volume and temperature are presented in Table 3.

A forthcoming state geothermal map compiled by the Arizona Bureau of Geology and Mineral Technology and published by the National Oceanographic and Atmospheric Administration will provide a complete and updated listing of data concerning thermal well and spring locations as well as temperature and depth estimates, flow rates and total dissolved solids. This map will be available in late 1981. ECONOMY

\section{Population}

Pima County was chosen for the second Area Development Plan since it contains the state's second largest population center, namely Tucson. With a 1980 population of 531,263 and an area of 9,240 square miles, Pima County has a population density of 57.5 persons per square mile. This figure can be misleading since the population is not uniformly distributed throughout the county but is concentrated in the Tucson area. The 1980 urban area population of Tucson was 487,263 giving it a population density of 1392 persons per square mile. Other major cities in the county are South Tucson, Ajo, Green Valley/Continental and Catalina. They are listed in Table 4 along with their populations. 
IABLE 3: INEGRRED INTERMEDIATE TO HIGI TEMPERATURE ( $>90^{\circ} \mathrm{C}$ ) GEOTHERMAL RESERVOIRS

OF PIMA COUNTY OF LESS THAN $2.5 \mathrm{KM}$ DEPTH

Tr - Average reservolr temperature

\begin{tabular}{ccccc}
\hline Name & Location & $\begin{array}{c}\text { Depth } \\
\mathrm{km}\end{array}$ & $\begin{array}{c}\text { Volyme } \\
\mathrm{km}\end{array}$ & $\mathrm{Tr}-{ }^{\mathrm{O}} \mathrm{C}$ \\
\hline Tucson Basin & T14-15S, R14-15E & 2.5 & 2.5 & 130 \\
\hline
\end{tabular}

1 luterences based on:
(1) Deep well tests
(2) Ceopliysics/heat flow
(3) Structure 
TABLE 4: MAJOR CITIES IN PIMA COUNTY AND THEIR POPULATIONS

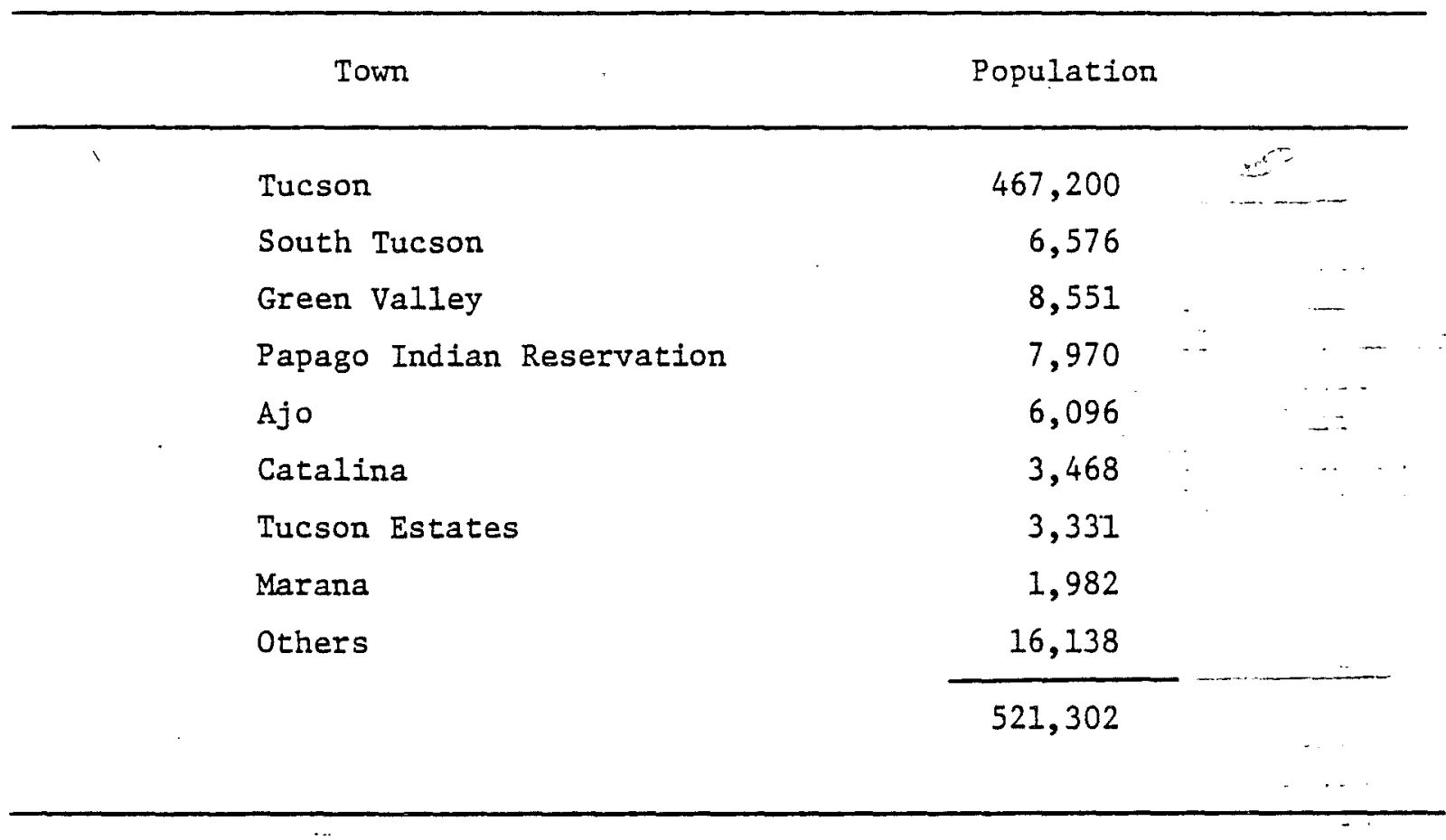

Of the 521,301 persons in Pima County, 69 percent are white, 24 percent are Hispanic, 3 percent are Indian and 3 percent are black.

Growth

Over the last 40 years, the population of Pima County has grown at an annual rate of 5.2 percent. . Future projections place population growth at 2.3 percent per year until the year 2000. However, many persons within Tucson believe these projections underestimate population growth. Many feel that the population of Tucson alone will exceed 1,000,000 people before 2000 . Figure 3 shows projected population for Pima County at the 2.3 percent growth rate and at various other growth rates as well. It is almost certain that the 2.3 percent figure is too low for Pima County.

The majority of growth is expected to occur in and around Tucson since it is the only major city in the county. Southwest Tucson is growing most rapidly followed by the northeast and northwest sections. Figure 4 shows the growth rates for areas of Tucson as measured by increases in school enrollment. 


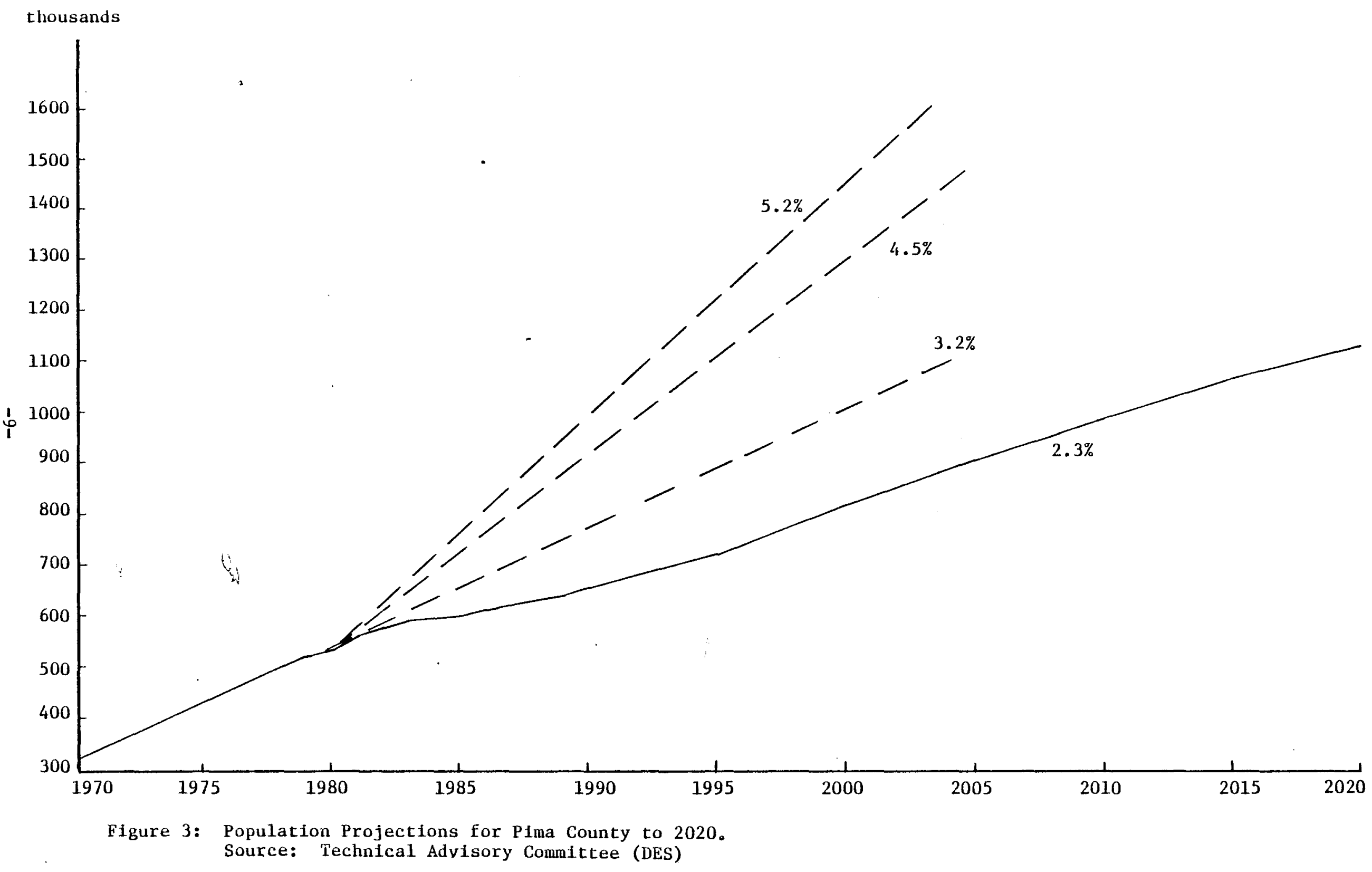




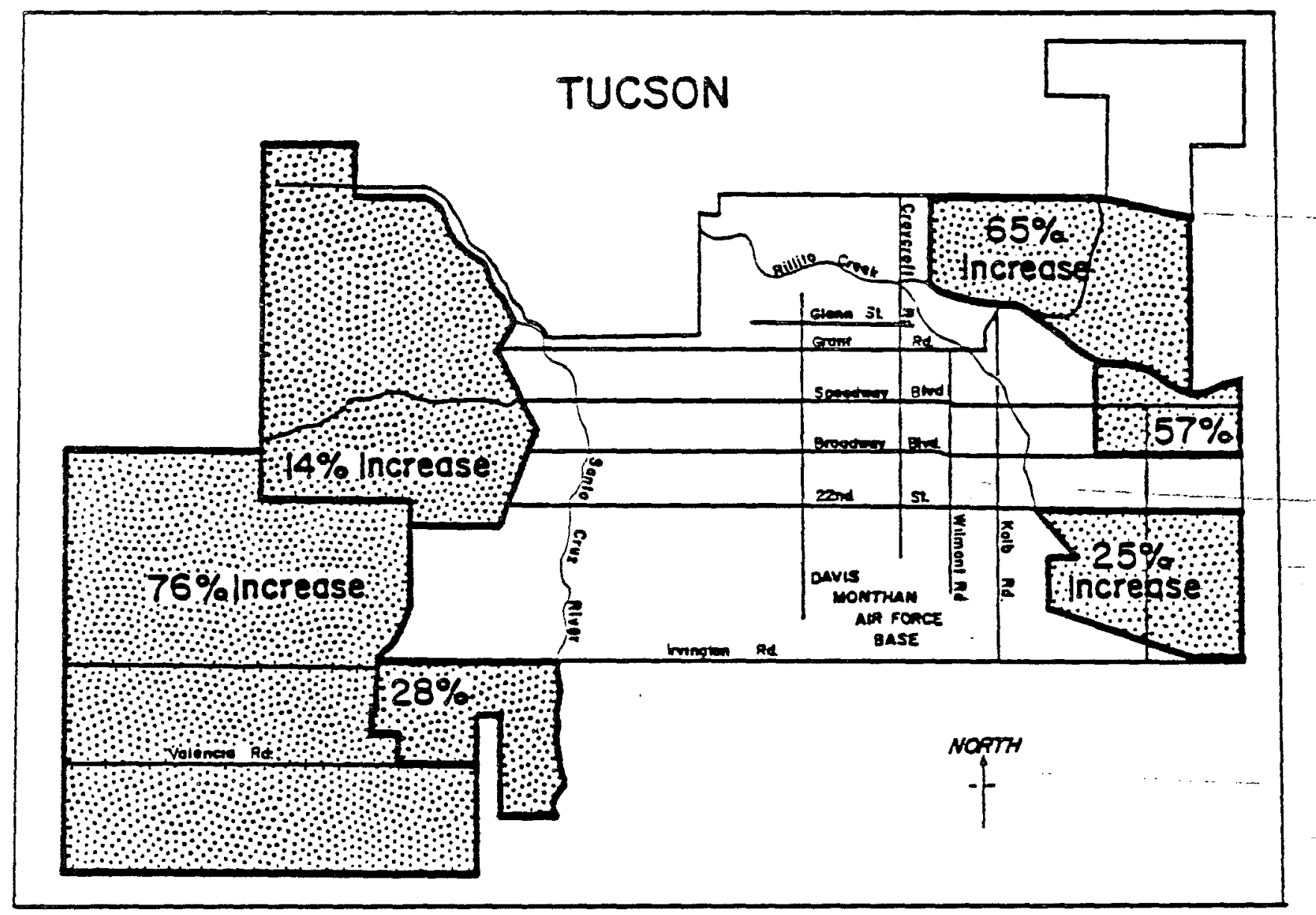

FIGURE 4: Fastest Growing Areas of Tucson. 


\section{Industry and Employment}

The principal contributor to Pima County's income is tourism, accounting for $\$ 900$ million in fiscal 1978 - 1979. This figure represents a 25-percent increase from the previous year. Although tourism in the county has shown rapid growth over the years, energy shortages may slow the growth in travel to Arizona and to Pima County.

The second largest contributor to the county's economy is manufacturing, specifically of aircraft and electronics products. Manufacturing accounted for an estimated 17,000 jobs in 1979 and contributed over $\$ 300$ million to the Pima County economy in 1977. The Department of Economic Security estimates that manufacturing employment will grow at an annual rate of over 5 percent, mostly in the Tucson metropolitan area.

The third largest contributor to the Gross County Product of Pima County is mining, specifically copper mining. Copper mining in Pima County accounted for about 40 percent of total production in Arizona in 1970. However, the copper industry fluctuates wildly depending upon the market price of copper and is only recently recovering from a 1977 slump.

Agriculture is also an important segment of the Pima County economy, accounting for over $\$ 44$ million in income in 1977. In 1978, a total of 46,000 acres was planted in Pima County, the majority of which were planted in cotton followed by grains, vegetables and alfalfa. The Department of Economic Security estimates that approximately 1500 persons were employed in agriculture in 1979. However, due to critical water problems, employment in agriculture is expected to decline 2.2 percent per year through the year 2000 .

Figures 5 and 6 give 1978 employment levels for various sectors as well as the expected levels in the year 2000. Overall employment in the 


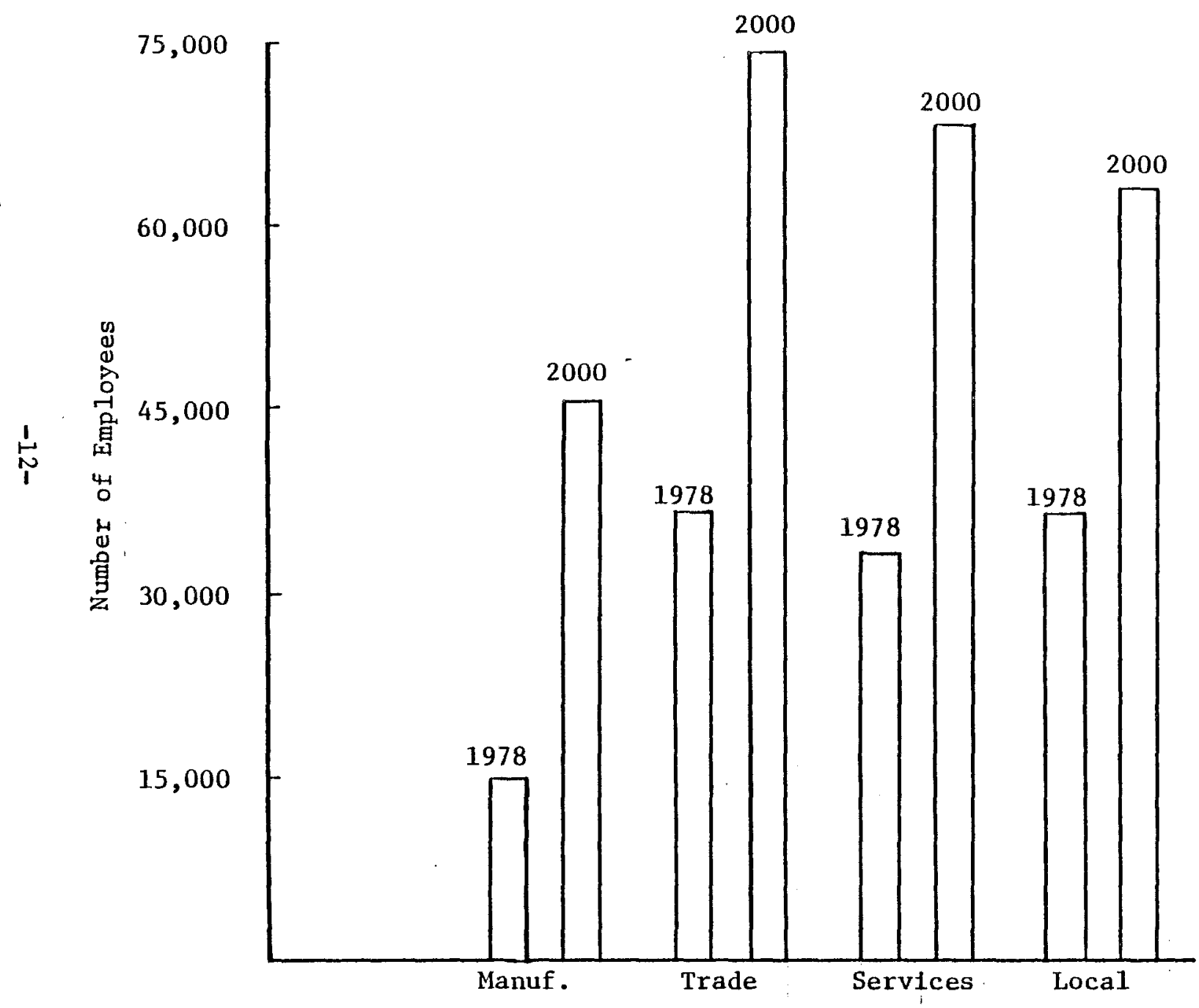

Figure 5: Major Employment Sector Projections for Pima County. Source: Department of Economic Security 


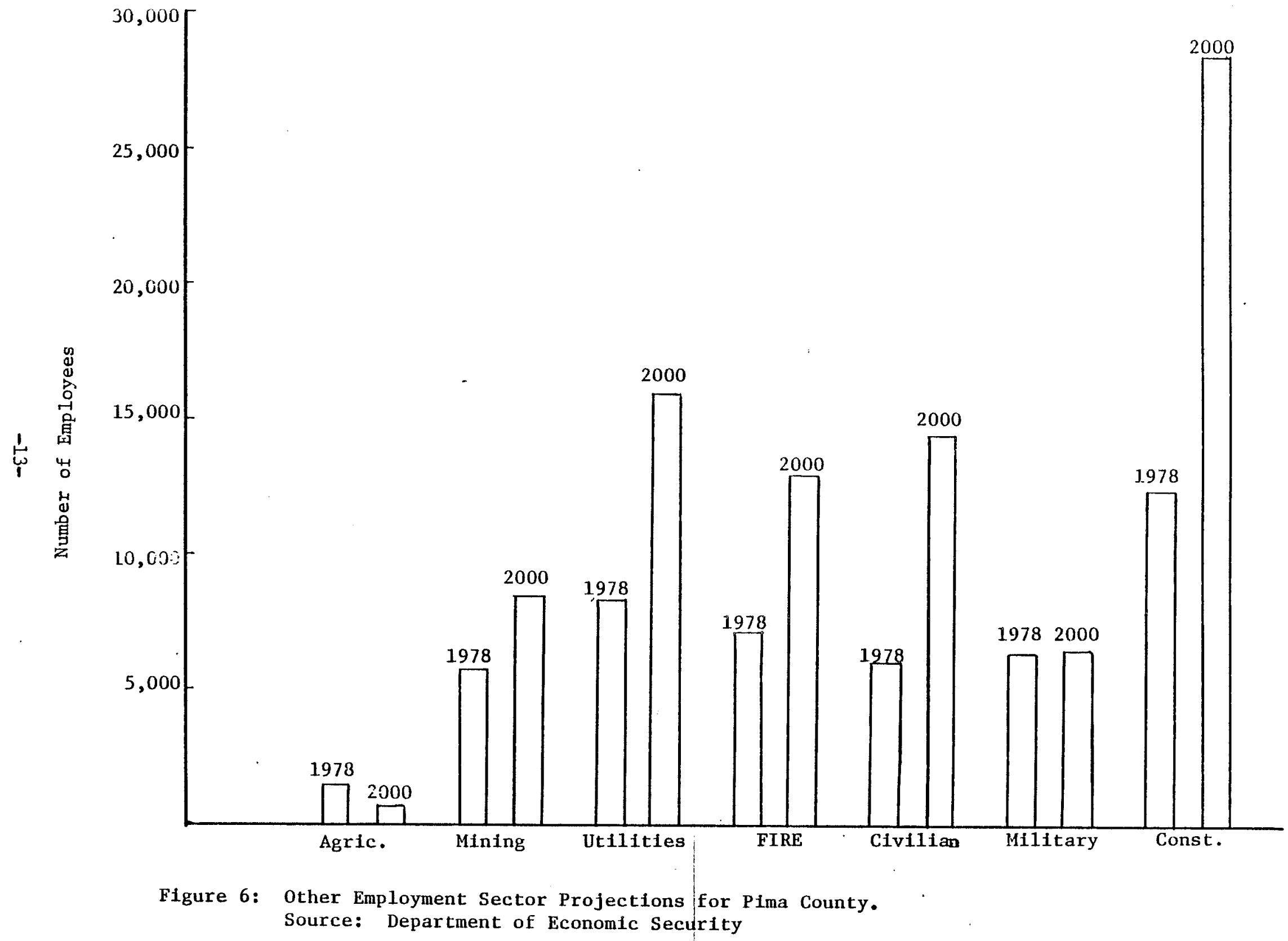


county is expected to grow at a 3.2 percent annual rate to 2000 . Most rapid growth is expected in the manufacturing sector followed by the civilian government labor force and the construction industry.

\section{Income}

Personal income and per capita income are considered strong indicators of the economic health of a region. Since there is a direct relationship between income and energy consumption, changes in personal income and per capita income are a reflection of both economic growth and energy consumption. During the period 1970-1977, aggregate personal income in Pima County grew by 12.5 percent per year. Figures 7 and 8 show projected growth of personal income and per capita income to the year 2000 as projected by the Department of Economic Security. This growth in income can be attributed to the predominance of high-wage industries such as manufacturing, construction and government.

Other Economic Indicators

The general welfare of the economy is indicated not only by such factors as population, employment and income but also by total retail sales and bank deposits. During the period 1968-1978, retail sales in Pima County grew by 215 percent; bank deposits increased by 180 percent over the same pertod. These figures further illustrate the continuing, rapid economic growth of Pima County.

In summary, the economic indicators investigated all point to continued economic growth within Pima County. In fact, the Chase Econometric Association found that Tucson is the fastest growing city in the United"states. In order to support this growth, large amounts of energy will be required for both the expansion of residential housing and the growth of industry and trade centers. It is believed that geothermal energy could provide some of the energy needed in the future. 

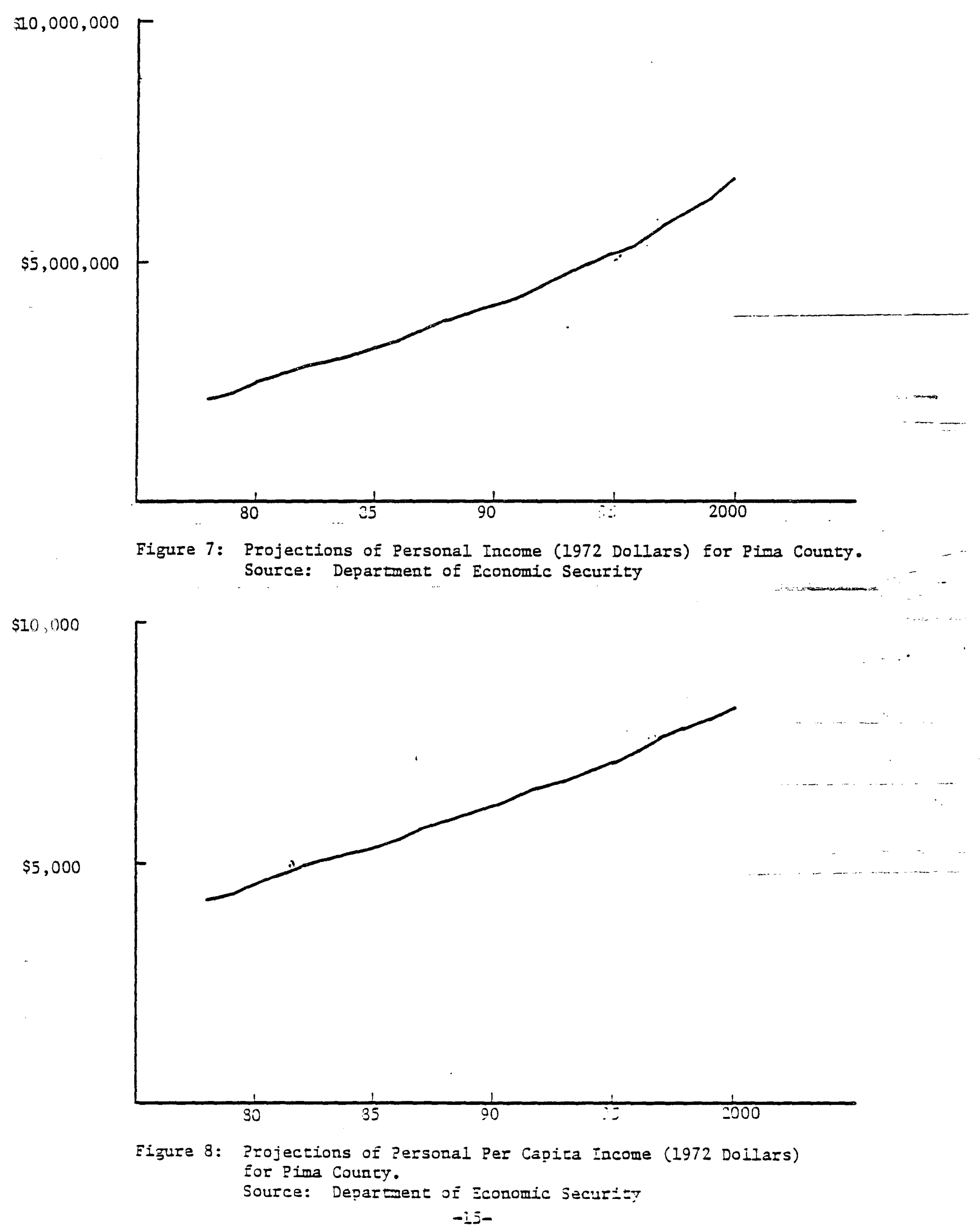


\section{LAND OWNERSHIP}

Figure 9 presents a general land ownership map for Pima County. The majority of the land is owned by the Indians. Table 5 presents acres owned by various sectors. Procedures for acquiring surface and mineral rights depend upon which sector owns the land.

TABLE 5: LAND OWNERSEIP BY ACRES

\begin{tabular}{lcc}
\hline Sector & Percentage & Acres \\
\hline Indian & 42 & $2,483,880$ \\
Federal & 28 & $1,655,920$ \\
State & 16 & 946,240 \\
Private & 14 & 827,960 \\
Total & 100 & $5,914,000$ \\
\hline
\end{tabular}

\section{ENERGY USE}

Table 6 presents energy use during 1978 for the various users within Pima County. Projections are also provided to illustrate expected trends in energy use. Estimated 1978 average prices for the energy types are presented by user class in Table 7 .

With the exception of electricity the energy price increases shown in Table 8 were based on Energy Information Administration projections to the. year 2020. These price increases reflect ragional trends not state trends. Western Regional price increases for fuel sources will probably reflect trends in Arizona. However, due to the current and projected excess electrical generating capacity for Pima County, price increases for electicity will be minimal through 2020 since rising fuel and labor costs are relatively insignificant wien compared to ghe sose of ners power plants. Inus, 


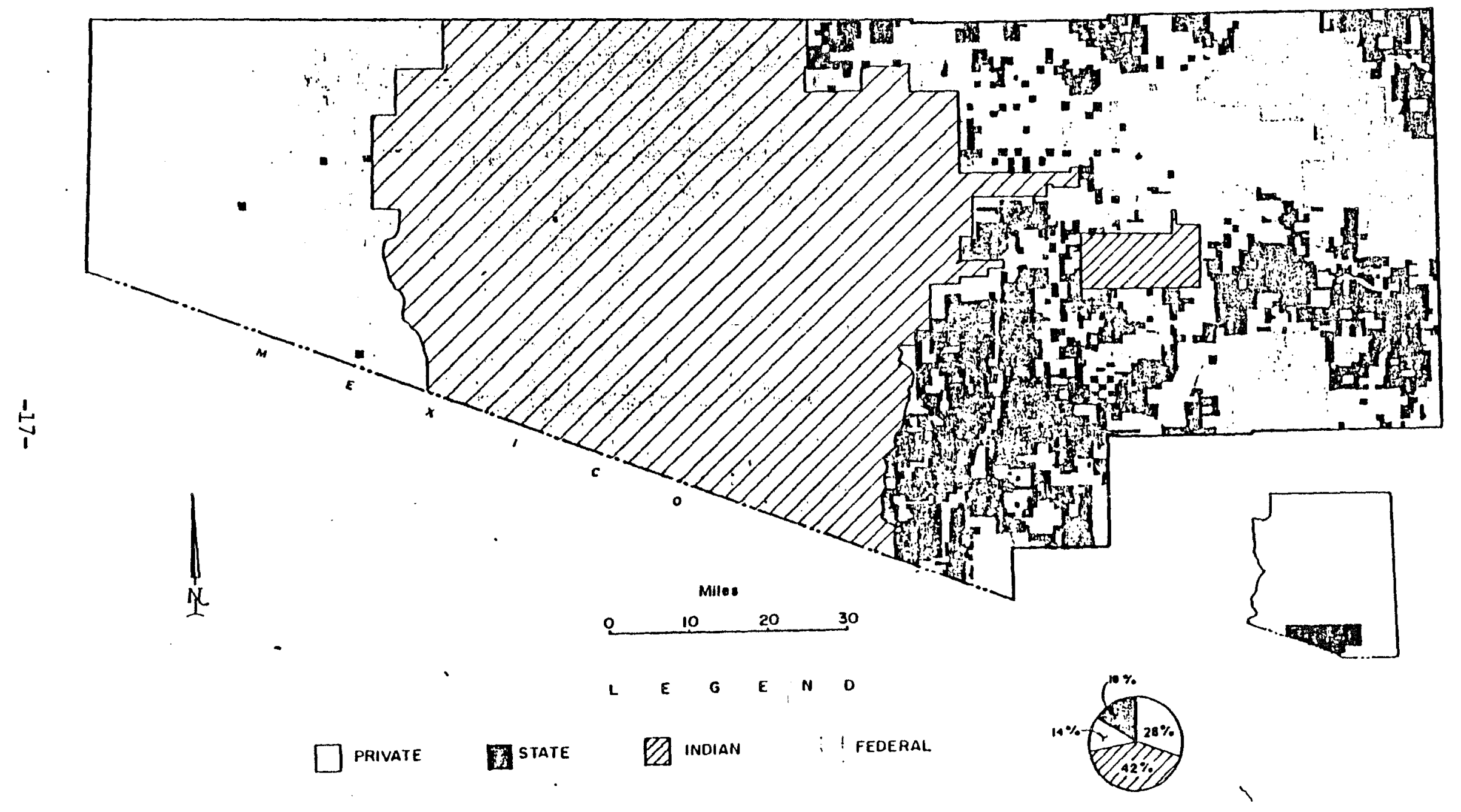

Figure 9: General Land Ownership Map for Pima County. 
TABLE 6: PIMA COUNTY ENERGY-USE PROJECTIONS (1) (Trillion Btu) -

\begin{tabular}{|c|c|c|c|c|c|}
\hline & User Class & $1978^{(2)}$ & $1985^{(3)}$ & 2000 & 2020 \\
\hline & Residential & 12.54 & 11.44 & 10.04 & 10.98 \\
\hline & Commercial & 14.72 & 16.24 & 22,40 & 45.28 \\
\hline & Industrial & 7.55 & 8.00 & 10.00 & 15.17 \\
\hline & Total & 34.81 & 35.68 & 42.44 & 71.43 \\
\hline (I) & \multicolumn{5}{|c|}{ Excludes transportation, conversion and line losses. } \\
\hline (2) & \multicolumn{5}{|c|}{$\begin{array}{l}\text { Developed from Arizona Energy Use 1978, by the } \\
\text { and Business Research, University of Arizona. }\end{array}$} \\
\hline (3) & \multicolumn{5}{|c|}{$\begin{array}{l}\text { Projections derived from growth rates from state projections per- } \\
\text { formed by New Mexico Energy Institute. }\end{array}$} \\
\hline
\end{tabular}

TABLE 7: ESTIMATED AVERAGE ENERGY PRICES BY USER CIASS, 1978 (Per Million Btu)

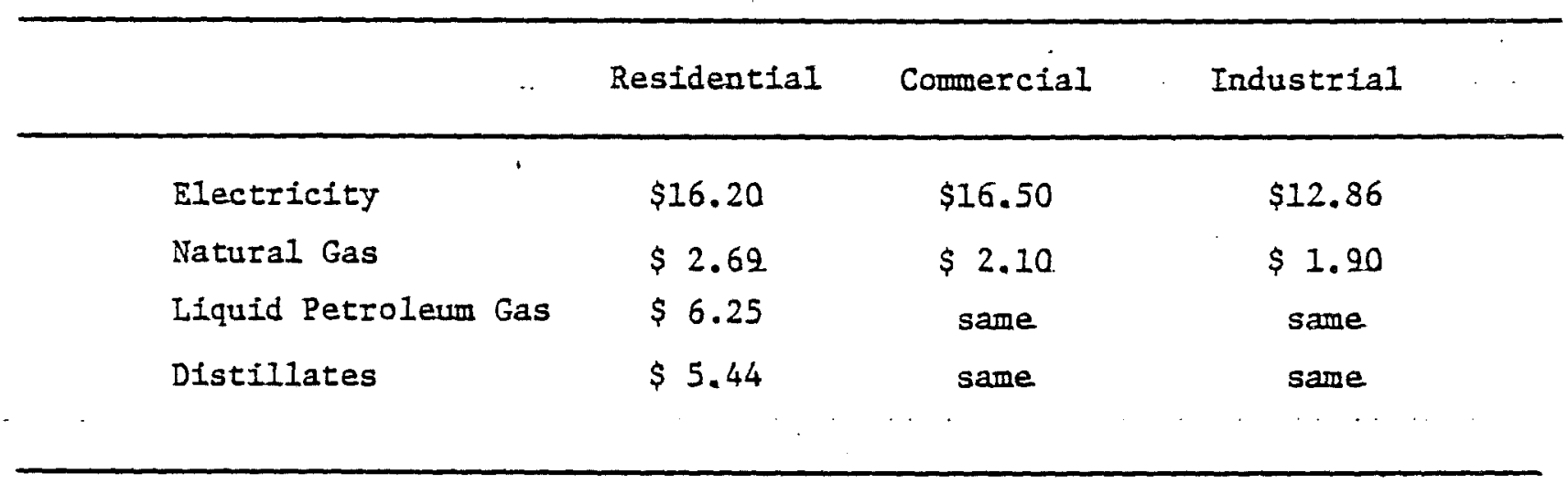


TABLE 8: REAL PRICE GROWTH RATES (By Fuel Type and Consuming Sector)

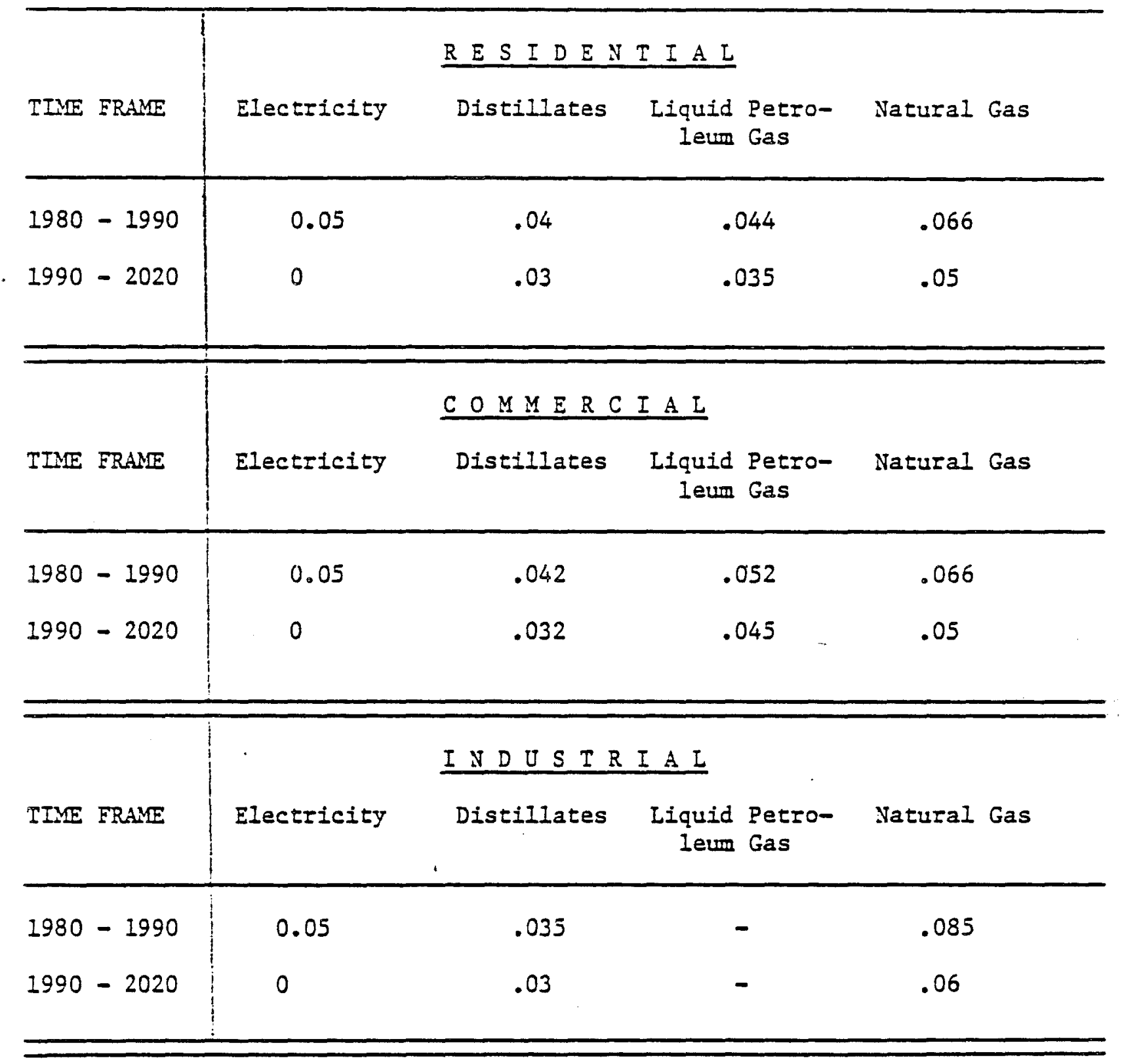

Source: Energy Information Administration (1979)

electricity price increases will experience less increase relative to increases in other fuel prices over the next forty years.

Excluding gasoline for transportation, electzicity and natural gas are the tro pajor types of enerzy consumed in Pina County. Table 9 Iists Ig78 Levels of sales Sor electricity and natural zas. 
TABLE 9: ENERGY USE BY USER CLASS, 1978

\begin{tabular}{|c|c|c|}
\hline & $\begin{array}{l}\text { Electric } \\
(\mathrm{MWh})\end{array}$ & $\begin{array}{l}\text { Natural Gas (2) } \\
\quad \text { (MMCF) }\end{array}$ \\
\hline Residential & $1,117,795$ & $7,866,457$ \\
\hline Comercial & $1,170,393$ & $5,079,622$ \\
\hline Large Users (3) & $1,883,692$ & $3,776,957$ \\
\hline Irrigation & 22,468 & 655,204 \\
\hline Total & $4,194,348$ & $17,378,240$ \\
\hline
\end{tabular}

1) Source is Tucson Electric Power \& Trico Electric

2) Source is Tucson Gas \& Electric \& Ajo Improvement Co.

3) Includes Large Commercial Users

Btu Equivalents (Trillion Btu's) Electric Natural Gas Total

\begin{tabular}{lccc}
\hline Residential & 3.815 & 7.866 & 11.681 \\
Commercial & 3.995 & 5.079 & 9.079 \\
Large Users (1) & 6.429 & 3.777 & 10.206 \\
Irrigation & $\frac{.0767}{14.3157}$ & $\frac{.655}{17.377}$ & $\frac{.7317}{31.6977}$ \\
Total & & & \\
\hline
\end{tabular}

1) Includes large commercial users. 
Tucson Electric Power Company provides electricity to 90 percent of the customers in Pima County. Curzent and projected breakdowns of energy sales are presented in Table 10. As indicated in the table, the industrial and large-user sector currently accounts for 50 percent of Tucsoñ Electric Power Company's total electric energy sales; in 1995, this figure is expected to decrease to 39 percent of the total sales.

TABLE 10: PROJECTED DPISTRIBUTION OF ELECTRICITY SALES IN PIMA COUNTY

\begin{tabular}{|c|c|c|c|c|}
\hline \multirow[b]{2}{*}{ Customer Class } & \multicolumn{3}{|c|}{ Percent of Sales } & \multirow[b]{2}{*}{1995} \\
\hline & 1980 & 1985 & 1990 & \\
\hline Residential & 26 & 30 & 33 & 35 \\
\hline Commercial & 19 & 20 & 20 & 22 \\
\hline Industrial \& Lagge Users & 50 & 46 & 42 & 39 \\
\hline Others & 5 & 4 & 5 & 4 \\
\hline Tucson Electric & Power & & . & \\
\hline
\end{tabular}

The residential sector, however, is expected to account for a larger percentage of total electric energy sales in 1995 (35 percent) than it currently does (26 percent). This increase is largely due to the expected population growth and increased demand for electric heating. The industrial sector has more flexibility than the residential sector and can modify its energy needs more easily. Thus, the industrial sector will noe have to rely as heavily upon electric power in the future as it does now, and percent of total electric energy consumed by the industrial sector can be expected to decrease. 
During 1979, data were collected for monthly electricity sales by user class. Figure 10 shows that the peak demand for electricity in the sumer months substantially tapered off in the winter months due to a decline in usage of electricity for space cooling. This pattern is also followed by the commercial and industrial sectors. Mining, however, shows a steady increase in demand throughout the year.

Associated with monthly electric saies is a daily load curve. Figure 11 11lustrates the capacity necessary to meet the daily peak in Pima County. On July 19, 1978 the annual peak of 833 IN was reached. It is this peak which defines the capacity in use and the capacity for which local utility companies must design their total systems.

Figure 12 presents growth in the peak as experienced by Iucson Electric Power Company between 1973 and 1979. The peak sumer load has grown an average of three percent per year since 1973. However, no change in the peak was experienced in 1974, 1975 or 1976, a reflection of a recession in Pina County and doubled electric rates. Tucson Electric Power Company is-required to maintain an additional margin of capacity above the annual peak. Over the period indicated, this margin has ranged from 24 percent to 69 percent of capacity, excluding sales for resale.

In some areas, different rates are charged for electric power based on the time of day the electricity is used. Higher sates are charged for electricity used durlng the day when the power company is operating on more expensive fuel types. This time-of-day pricing is currently in the experimental stage.

Southwest Gas Corporation provides natural gas to Pina County. Revenue provides the tlosest estinate of fis ratural gas sales since Soutimest Gas 


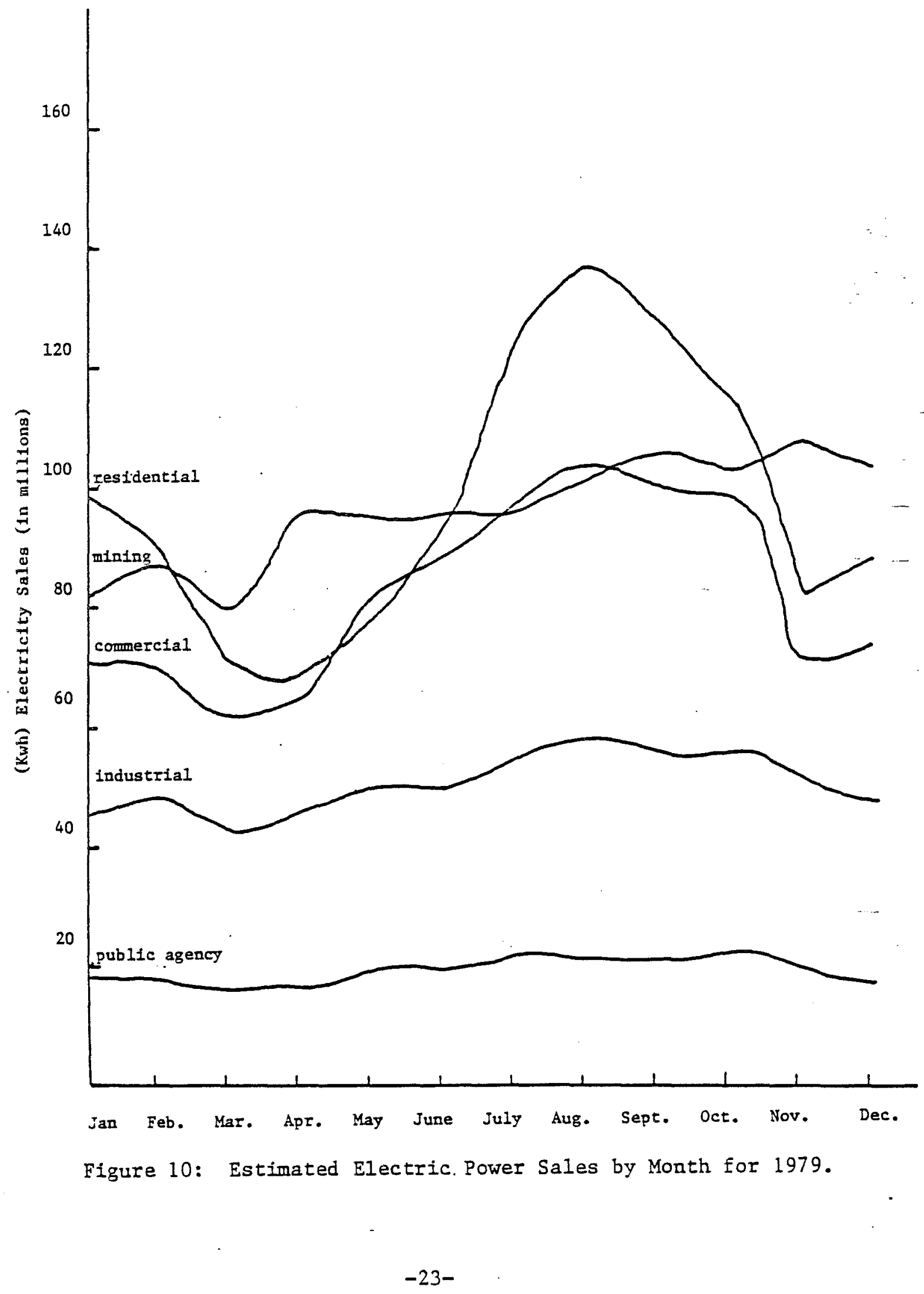




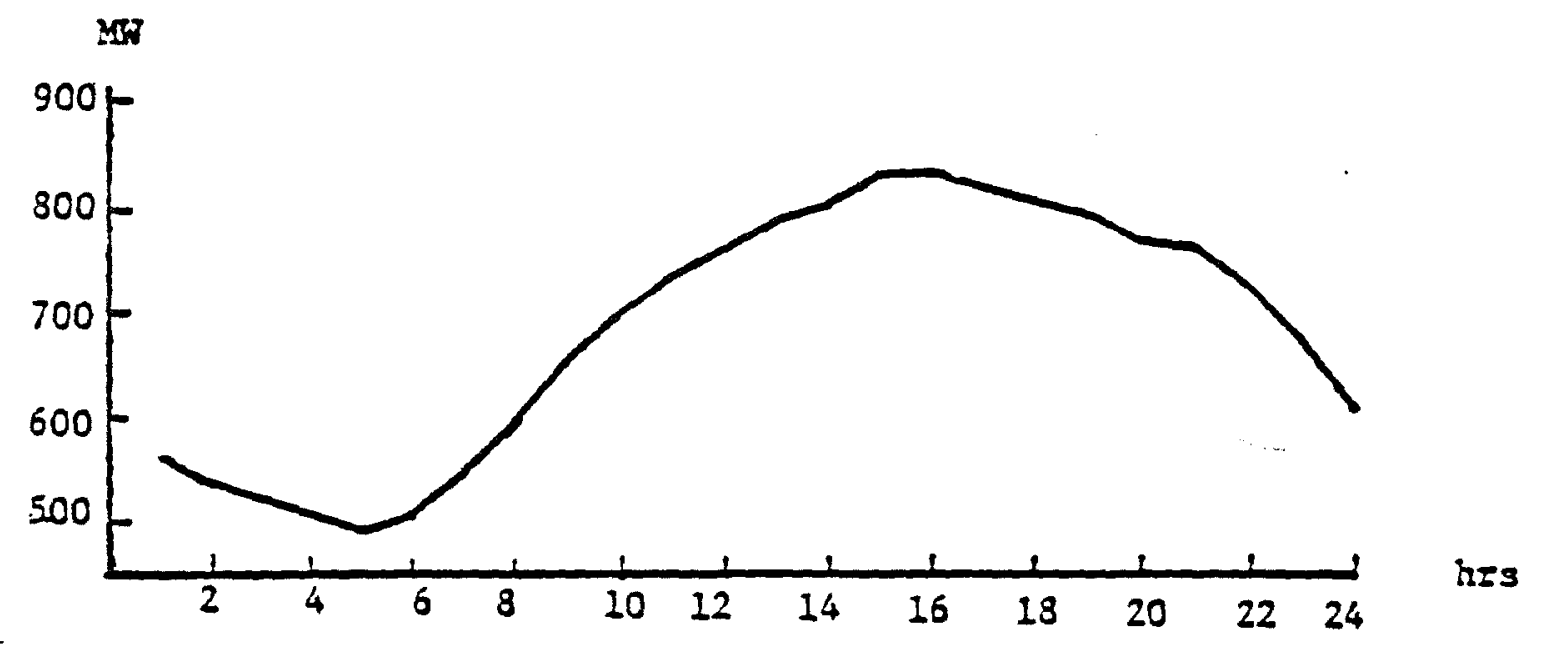

Figure 11: Daily Load Curve for Tucson Electric Power Co., July 19, 1978. Peak Load - 833 WW 


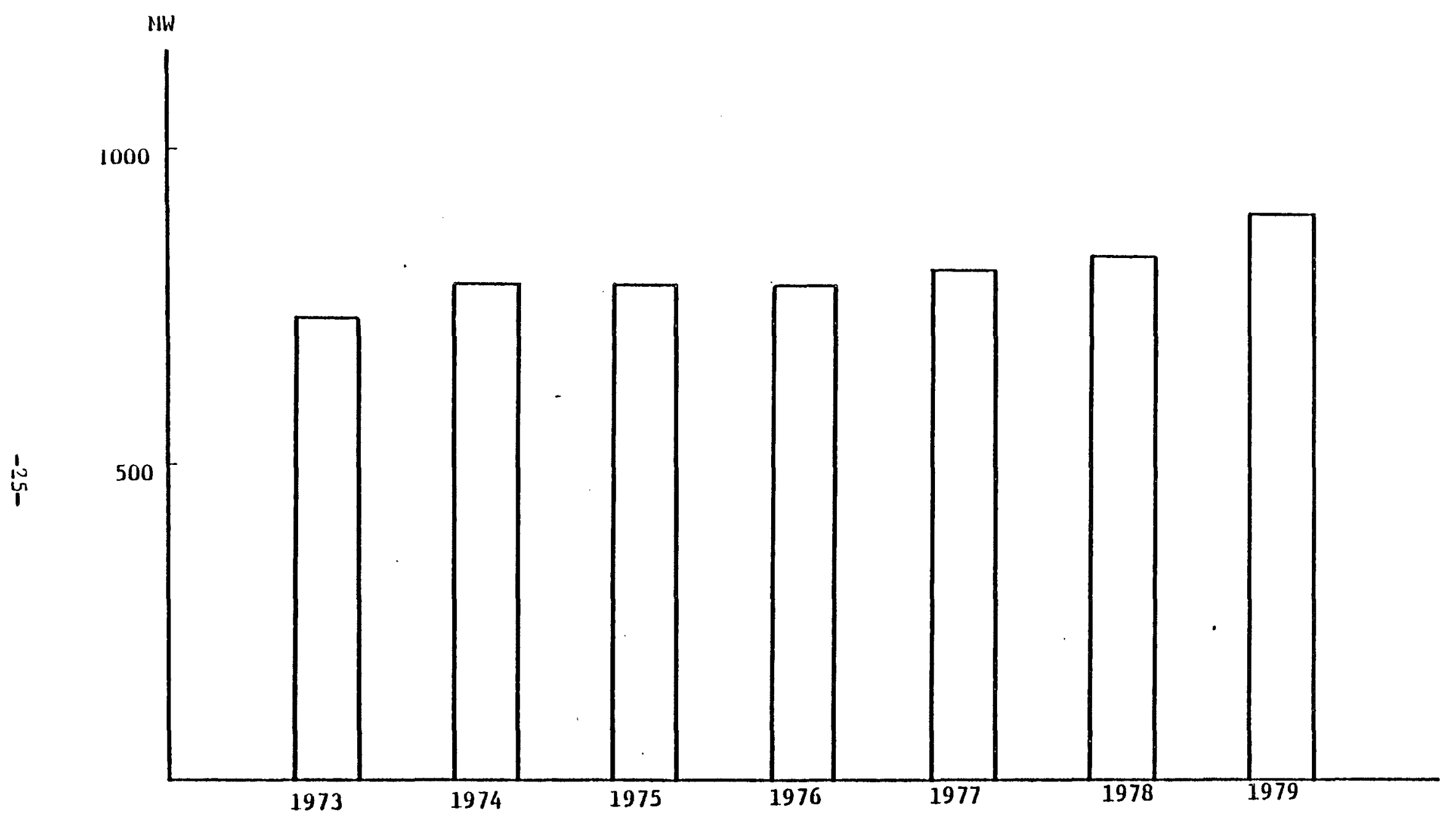

Plgure 12: Peak Electric load, 1973 - 1979. Source: Tucson Electric Power Co. 
Corporation does not collect monthly sales data. Booked volume sales, revenues received during the month for previous sales, for 1979 are presented in Figure 13. As anticipated, natural gas sales show peak demand for residential and commercial consumption for space heating in the winter months. The majority of residential dwellings in Tucson and the surrounding area use natural gas heating.

WATER

Water is rapidly becoming the major constraint to growth in Pima County. In Figure 14, the three alternative futures for water availability and use indicate that water demand currently exceeds and will continue to exceed dependable supplies. Demand for water will increase with the projected increases in population and mining activity. The Alternative Futures Sumary shows that under each alternative, urban depletions in 2020 will exceed current urban depletions by at least 24 acre-feet. Also, the alternatives indicate that water use for mining will increase nearly 100 percent by 1990 and 350-500 percent by 2020 .

Currently, Pima County's water supply comes entirely from underground sources which are rapidly being depleted. Central Arizona Project deliveries to Ptma County will more than double the county's current dependable supply. Even the increased supplies, however, will not be enough to meet the increased demand. Only under Alternative III is water supply even approximately equal to water demand. Under this alternative, water for harvested acres and agricultural use has been greatly reduced or eliminated. Thus, in order to have enough water Eor urban growth and aining, zgriculture will have to be drastically reduced over the next 40 years. 


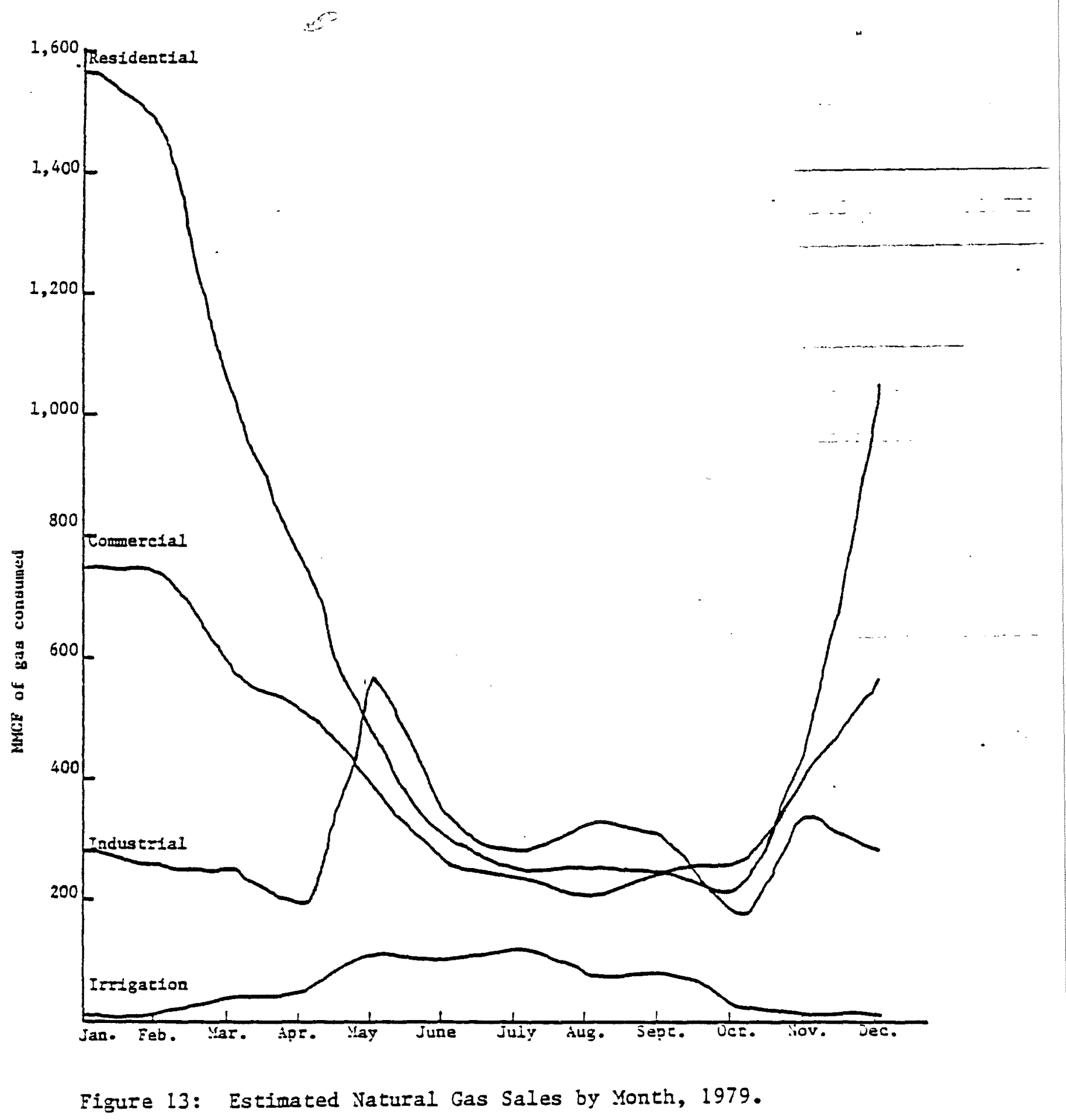




\section{PIMA COUNTY}

\section{ALTERNATIVE FUTURES}

\section{PROJECTED ALTERNATIVE WATER DEPLETIONS AND DEPENDABLE SUPPLY}

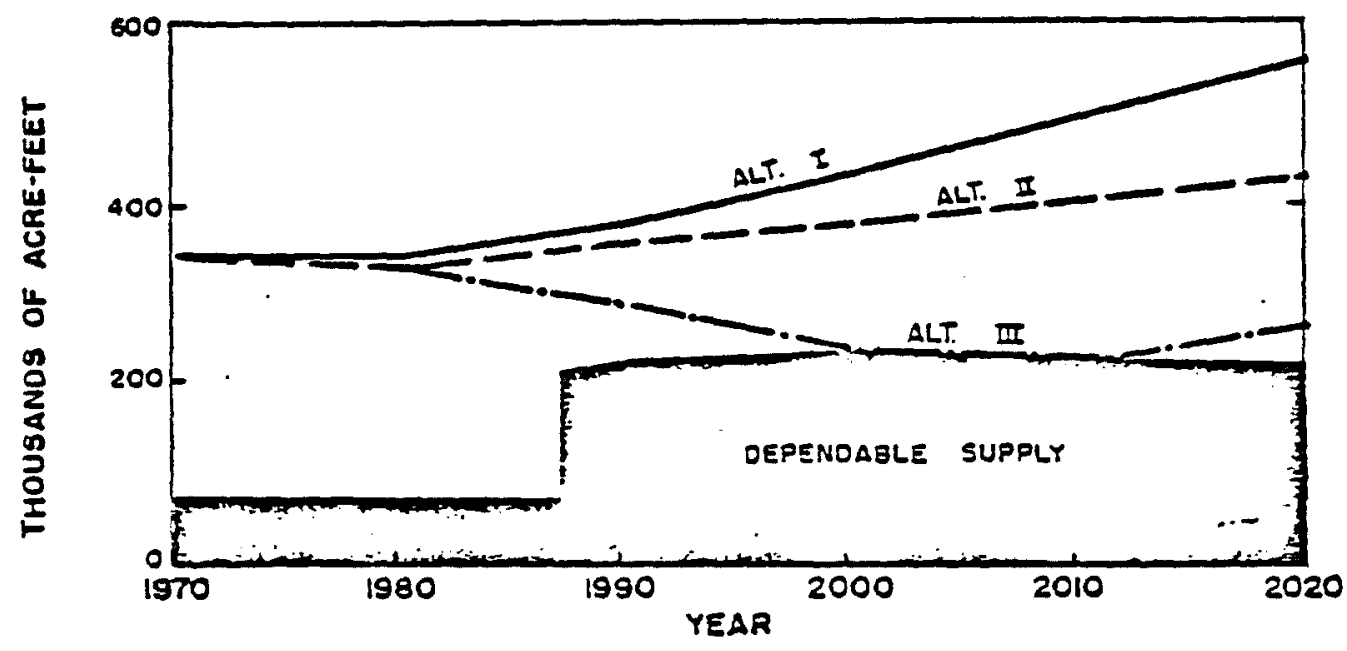

\section{ALTERNATIVE FUTURES SUMMARY}

\begin{tabular}{|c|c|c|c|c|c|c|c|}
\hline \multirow{3}{*}{$\begin{array}{c}\text { MEI } \\
\text { (Ouentilte in Thousands) }\end{array}$} & \multirow[b]{3}{*}{1970} & \multicolumn{4}{|c|}{ MTERMATIVE } & \multicolumn{2}{|c|}{ FUTURES } \\
\hline & & \multicolumn{2}{|c|}{1} & \multicolumn{2}{|c|}{ II } & \multicolumn{2}{|c|}{ III } \\
\hline & & 1990 & 2020 & 1990 & 2020 & 1990 & 2020 \\
\hline POPULATION & 3320 & 790.0 & 1490.0 & 645.0 & 960.0 & 645.0 & 960.0 \\
\hline HARVESTEO ACAES & 54.0 & 539 & 54.0 & 53.4 & 32.6 & 34.0 & 0 \\
\hline UABAN DEPLETIONS AFNA & $\infty .1$ & 79.0 & 14.0 & 84.7 & 93.1 & 64.7 & 931 \\
\hline STEAM ELECTAIC DEPLETIONS AFMR & 4.1 & 4.4 & 7.8 & 34 & 5.8 & 34 & 5.8 \\
\hline MINEAAL DEPLETIONS AFTYA & 530 & 101.0 & 2400 & 1000 & 170.0 & 180.0 & 170.0 \\
\hline AGAICULTUAAL DEPL AF/YR & 211.0 & 1960 & 1720 & 194.0 & 188.0 & 123.0 & 0 \\
\hline TOTAL WATER DEPL AFMR & 330 & 380 & $\operatorname{sen}$ & 362 & $\boldsymbol{s}$ & 291 & 269 \\
\hline DEPENOABLE WATEA AF/YA & $\boldsymbol{\pi}$ & 228 & 225 & 228 & 225 & 228 & 225 \\
\hline SUAPLUS SUPPQY (Det.) & (250) & (152) & (3299) & (134) & $(212)$ & (83) & (4) \\
\hline
\end{tabular}

Eigure 14: Projecred Alternatives for Water Use in Pima County. suurce: irizona ivater Comission ( 1977 ) 
MATCHING GEOTHERMAI RESOURCES TO POTENTIAL USERS

The final aim of the ADP is to match potential users of geothermal energy to potential resources. An attempt is also made to define a time frame in which geothermal resources will realize comercial use.

Several approaches were taken to match potential users to geothermal resources. One approach concentrated on the industrial sector within Pima County. OnIy those industries whose process heat requirements are less than the assumed reservoir temperature of $100^{\circ} \mathrm{C}\left(212^{\circ} \mathrm{F}\right)$ were considered potential users of geothermal energy. Table 11 presents an estimate of process heat requirements for such industries within the county. It should be noted that industrial process heat requirements do not include energy consumed for space heating and cooling.

Estimated annual energy consumption was then used to model the introduction of geothermal energy into the process beat market. Projections of the amount of geothermal heat on line as a function of time over the next forty years resulted from work performed in conjunction with the New Yexico Energy Institute (NMEI). Figures 15 and 16 illustrate time line results for private development and city development, respectively, with differences between the two types of development primarily arising due to differing capital costs. The results indicate that under city utility development, geothermal energy could be cost competitive by 1983 whereas under private development geothermal energy would come on line by 1988. In essence, city utility development would result in faster development of geothermal energy. 
TABLE 11: ESTIMATED PROCESS HEAT ENERGY REQQUIREMENTS

FOR SELECTED INDUSTRIES IN PIMA COUNTY

Assumed Reservoir Temperature: $100^{\circ} \mathrm{C}\left(212^{\circ} \mathrm{F}\right)$

SIC Code $\begin{gathered}\text { Number } \\ \text { of Firms }\end{gathered} \quad$ Description

Energy Use

$\mathrm{Btu} / \mathrm{yr} \times 10^{\circ}$

\begin{tabular}{|c|c|c|c|}
\hline 2026 & 2 & Fluid Mild & 12.27 \\
\hline 2086 & 11 & Soft Drinks & 147.8 \\
\hline 2097 & 6 & Ice & 6.76 \\
\hline 2431 & 7 & Millwork & 18.9 \\
\hline 2499 & 3 & Misc. Wood Products & 147.2 \\
\hline 2511 & 9 & Wood Furniture & 17.62 \\
\hline 2515 & 2 & Mattresses & 2.1 \\
\hline 2519 & 3 & Mfsc. Furniture & 1.1 \\
\hline 2522 & 1 & Metal Office Furniture & 49.1 \\
\hline 2591 & 3 & Drapery Hardware & 3.5 \\
\hline 3161 & 1 & Luggage & 5.1 \\
\hline 3171 & 1 & Handbags & 1.0 \\
\hline 3273 & 5 & Ready-Mixed Concrete & 55.62 \\
\hline 3281 & 12 & Cut Stone Products & 3.04 \\
\hline 3441 & 6 & Structural Metal & 42.4 \\
\hline 3442 & 5 & Metal Doors & 17.2 \\
\hline 3443 & 2 & Botler Shops & 3.7 \\
\hline 3444 & 9 & Sheet Metal Work & 145.9 \\
\hline 3449 & 2 & Misc. Metal Work & 39.43 \\
\hline 3452 & 1 & Nuts/Bolts/Screws & 5.0 \\
\hline 3471 & 1 & Metal Plating & 7.7 \\
\hline 3496 & 1 & Wire Products & 0.09 \\
\hline 3499 & 6 & Misc. Metal Products & 11.2 \\
\hline 3519 & 1 & Internal Combustion Engines & 8.391 \\
\hline 3811 & 3 & Engineering Instruments & 3.9 \\
\hline 3841 & 1 & Medical Instruments & 16.8 \\
\hline 3843 & 1 & Dental Equipment & 0.4 \\
\hline 3911 & 1 & Jewelry & 0.5 \\
\hline 3914 & 1 & Silverware & 10.8 \\
\hline 3949 & 3 & Sporting Goods & 6.291 \\
\hline 3953 & 2 & Marking Devices & 1.1 \\
\hline 3999 & 3 & Misc. Manufactured Products & 166.3 \\
\hline
\end{tabular}




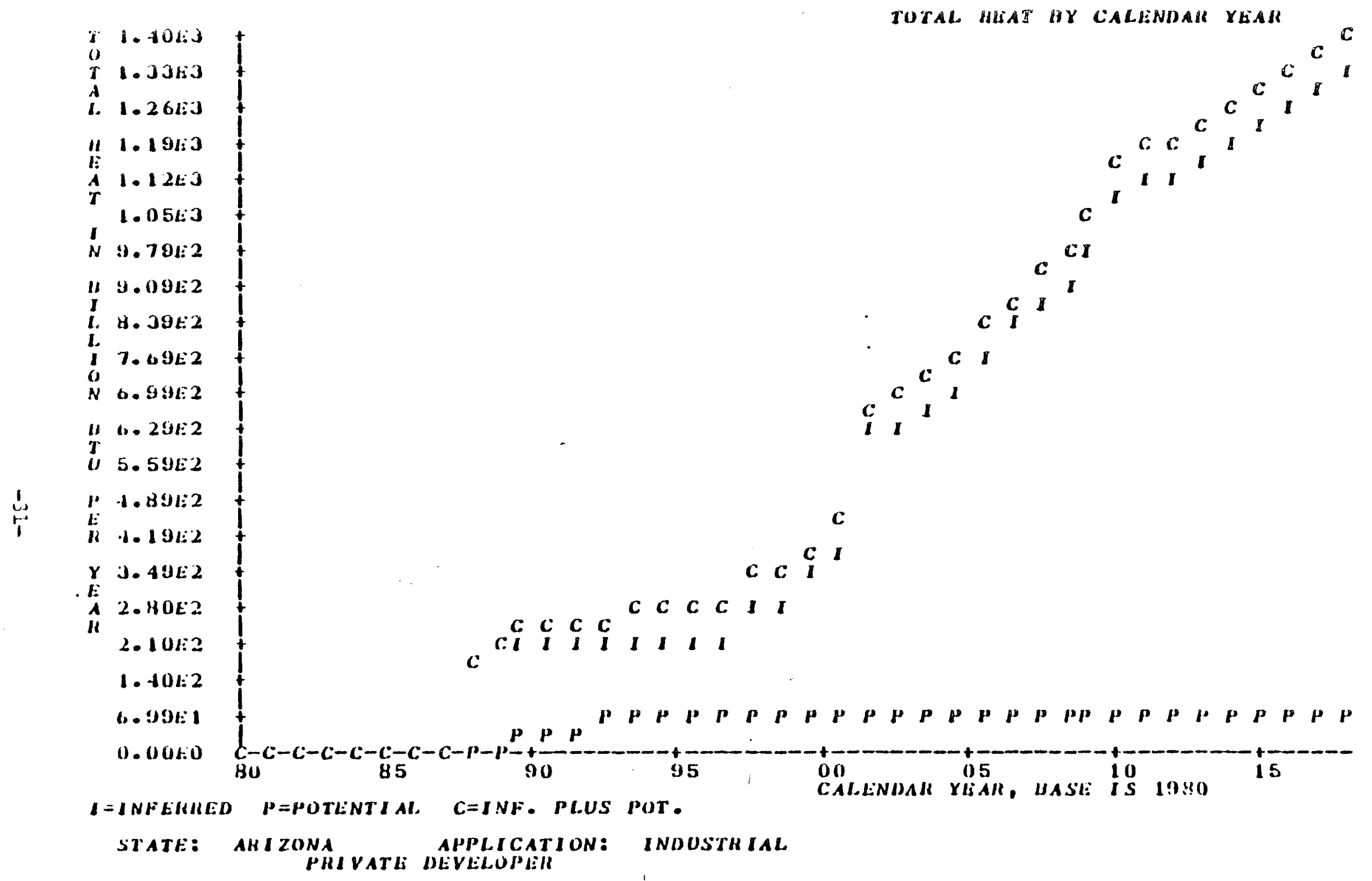

ligure 15: Projected Ceothermal lleat on LIne Under Private Development. Source: New Mexico linergy Institule 


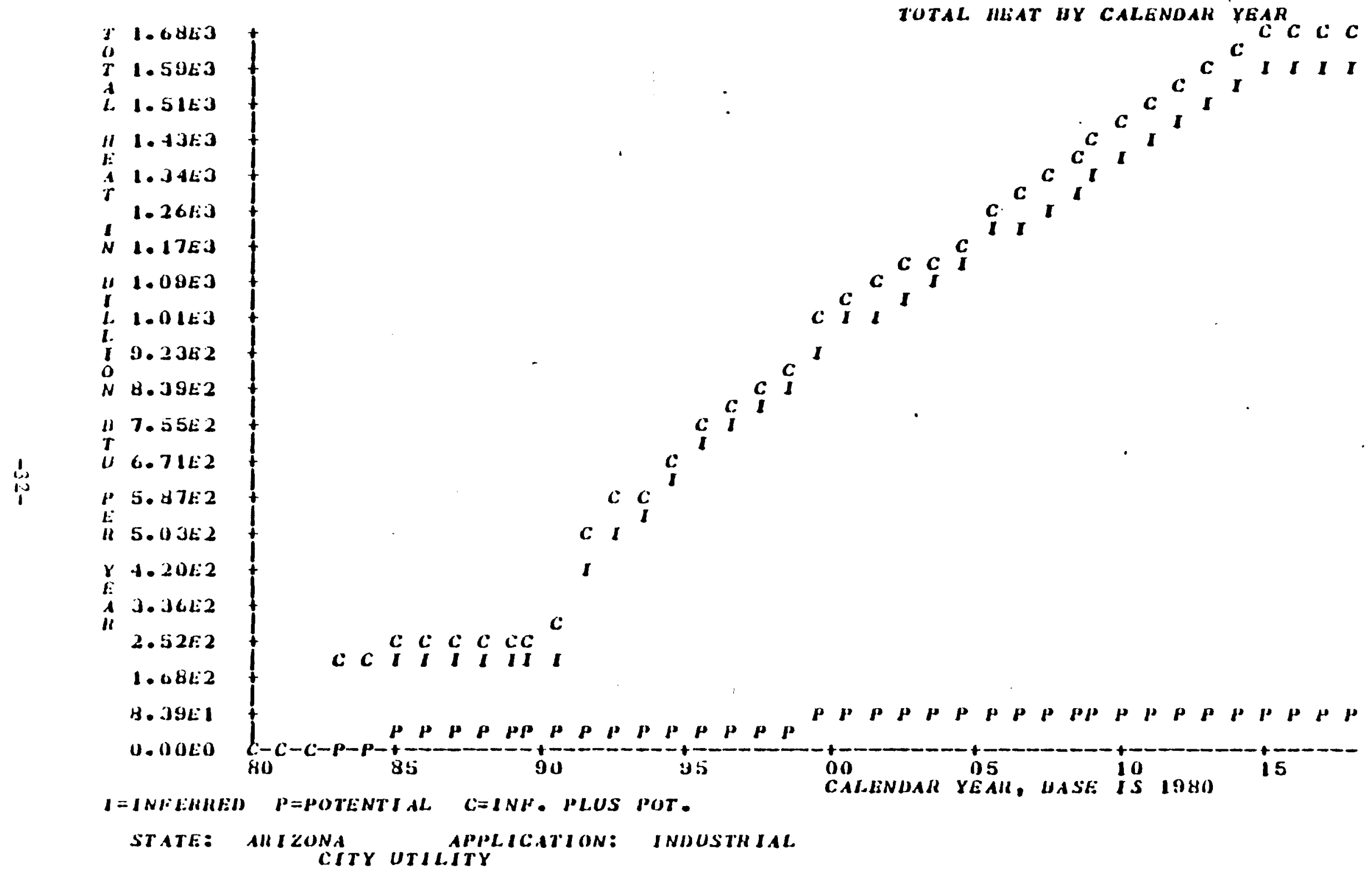

Plgure 16: Profected Geothermal Heat on line Under city Development. Source: New Mexico Energy Institute 
For comparison, the results of the modeling are presented in Table 12 in terms of barrels of oil replaced by geothermal energy. Clearly, geothermal energy's contribution to the process heat market could save a significant number of barrels of oil before 1990 and would be expected to contribute even more energy past 1990. The NMEI model is discussed more fully in Appendix A.

TABLE 12: BARRELS OF OIL REPLACED BY GEOTHERMAL ENERGY PER YEAR Process Heat Market

\begin{tabular}{lcccc}
\hline & 1985 & 1990 & 2000 & 2020 \\
\hline Private Developer & 0 & 44,643 & 87,320 & $250,000-$ \\
City Utility & 45,000 & 58,930 & 180,357 & 300,000 \\
\hline
\end{tabular}

Modeling was also performed for the residential and commercial sectors. However, the scope of work was confined to space heating energy requirements. It is believed that the space heating market in Pima County is limited to a few winter months and as such would not justify the establishment of district heating systems. Therefore, results from the residential and commercial sectors have been omitted until a system including space heating and space cooling can be modeled.

In a second approach to identify potential users of geothermal energy, industrial parks, industries, shopping centers, schools and hospitals located in southern Tucson were identified. These facilities may consume enough energy each year to warrant conversion to geothermal energy for space heating and cooling. The names of these facilities and their addresses are listed in Appendix B. 
Agribusiness and agriculturally related industries in Tucson are also identified. Tucson has five agricultural chemical operations, three cattle raising operations, one large dairy, nine meat packing plants and eight poultry farms. Any of these operations may be able to use geothermal energy in their operations in place of conventional energy sources.

Geothermal energy may also have process heat applications in the primary copper, soft drink and ready-mix concrete industries. The 1980 Directory of Arizona Manufacturers identifies industries by a four-digit SIC code and estimates of annual energy consumption as well as the process temperatures required by these industries were provided by the Solar Energy Research Institute. Information on the specific heat temperatures needed in each of the operations within these industries was gathered from three principal sources: the Noyes Data Corporation publication entitled "Energy-Saving Techniques for the Food Industry;" Drexel University's Energy Analysis of 108 Industrial Processes, Phase I of an Industrial Applications Study, 1979; and a Survey and Analysis of Solar Process Heating Opportunities in Arizona prepared by the University of Arizona.

Primary Copper (SIC 3331)

Pima County, the largest copper producer in Arizona, provides 40 percent of the copper produced in the state. There are about 2,200 million tons of proven copper ore in the state.

The typical process heat requirements for copper smelting and refining are sumarized in Table 13. Process heat requirements exceed $1090^{\circ} \mathrm{C}\left(2000^{\circ} \mathrm{F}\right)$ for all processes except solution heating. 
TABLE 13: TYPICAL PROCESS HEAT CONSUMPTION IN THE COPPER INDUSTRY

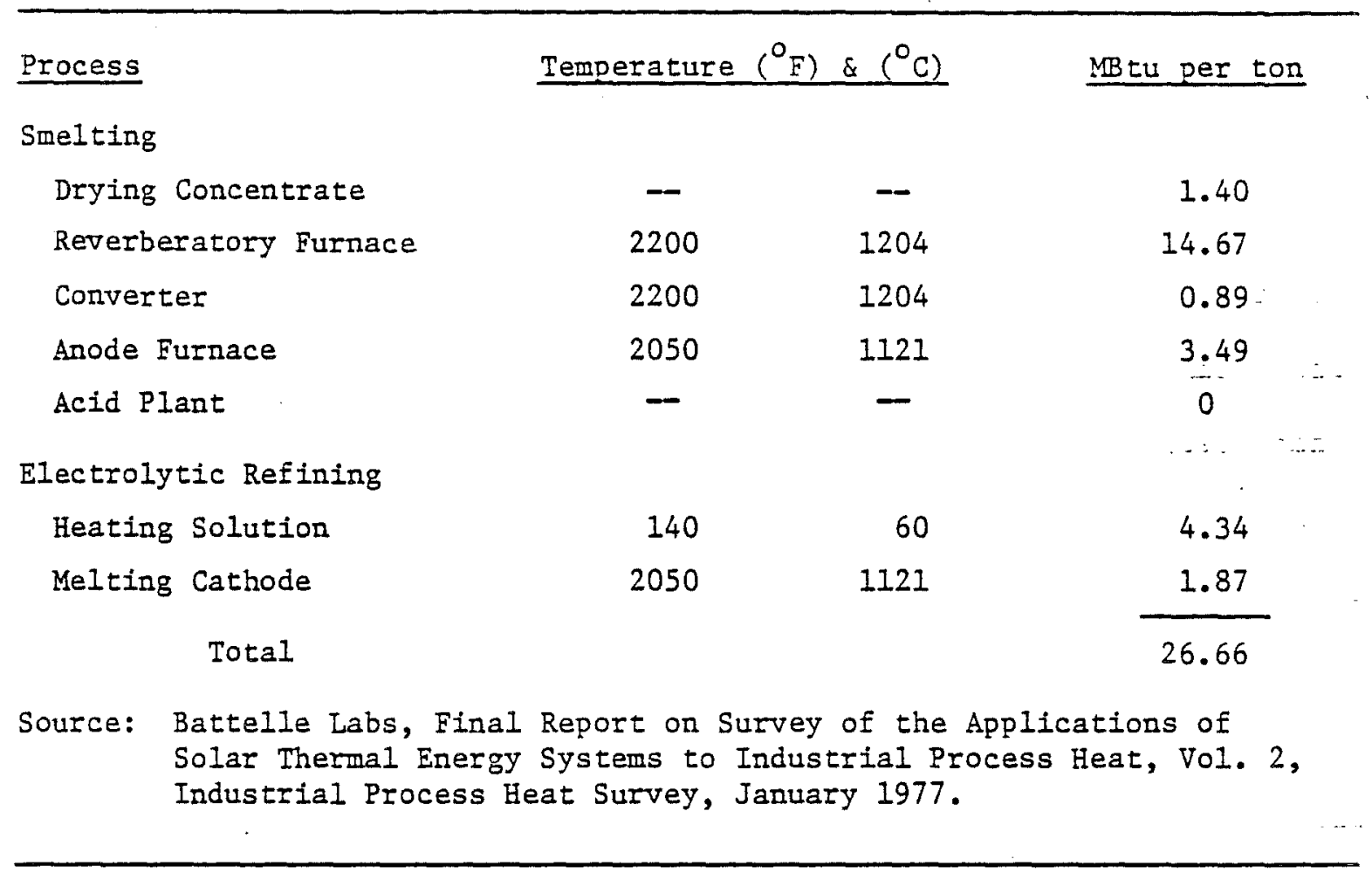

Drying the copper concentrate requires the same total amount of energy whether the concentrate is dried prior to or during the smelting process. In Arizona, no direct drying process is involved since the smelters use a wet charge of copper concentrate. Electricity is used during the smelting process, but if geothermal energy was used to predry the concentrate about $1.4 \times 10^{12} \mathrm{Btu}$ 's of conventional fuel could be displaced annually. This represents about four percent of the total thermal energy used by this industry.

The electrolytic refining process uses process heat in the range of $60^{\circ} \mathrm{C}\left(140^{\circ} \mathrm{F}\right)$ to $77^{\circ} \mathrm{C}\left(170^{\circ} \mathrm{F}\right)$ to heat electrolytic solutions. Heating the solutions requires $4.34 \mathrm{MBtu}$ per ton of refined copper; the total energy required annually for this process is about $1.2 \times 10^{12}$ Btu. Presently, most of the heat is supplied by natural gas and fuel oil. However, low temperature geothermal energy could be applied to this process. 
Table 14 indicates the use of process heat for the Individual processes within the primary and secondary copper industry.

TABLE 14: AGGREGATE PROCESS HEAT REQUIREMENTS FOR

PRIMARY AND SECONDARY COPPER

Trillion Btu's/year, 1973

Process

Copper (primary \& secondary)

Drying

Reverberatory Furnace

Converting

Anode Refining

Electrolytic Refining

Process

Copper (primary \& secondary)

Drying

Reverberatory Furnace

Converting

Anode Refining

Electrolytic Refining
Hot Water

under $100^{\circ} \mathrm{C}$

$100-177^{\circ} \mathrm{C}$ over $177^{\circ} \mathrm{C}$

$\begin{array}{ccc}0 & 0 & 0 \\ 0 & 0 & 0 \\ 0 & 0 & 0 \\ 0 & 0 & 0 \\ 4.6 & 0 & 0\end{array}$

Direct Heat/Hot Air under $100^{\circ} \mathrm{C} \quad 100-177^{\circ} \mathrm{C}$

over $177^{\circ} \mathrm{C}$

Source: See Table 13 for Source

A new copper refining process has recently been developed which offers possibilities for geothermal applications. The new process is a hydrometallurgical extraction of copper. This process is a low energy-consuming process with an assessed total energy requirement of $32 \mathrm{MB}$ tu/ton. The process energy required for solution heating is normally provided by 30-psi steam at a temperature of approximately $121^{\circ} \mathrm{C}\left(250^{\circ} \mathrm{F}\right)$. The solution 
temperatures required for this process are about $37^{\circ} \mathrm{C}\left(100^{\circ} \mathrm{F}\right)$ to $107^{\circ} \mathrm{C}$ $\left(225^{\circ} \mathrm{F}\right)$. Since the assessed geothermal reservoir temperature for Pima County is $100^{\circ} \mathrm{C}\left(212^{\circ} \mathrm{F}\right)$, the required solution temperatures are suitable to geothermal application.

In addition, it is important to note that copper dump leaching is practiced in some form in all of the mines in Pima County. Increased temperatures of the leaching fluid are known to enhance the rate of copper extraction. Low-temperature geothermal energy could be used in place of fossil fuels to heat the leaching fluid. Two reports being prepared by the Comercialization Team will discuss the leaching process for copper recovery. These reports, entitled "Geothermal Energy for Copper Dump Leaching" and "Geothermal Energy for the Extraction of Copper by Elotation", should be available by late 1981.

Soft Drink Industry (SIC 2086)

The 1980 Arizona Directory of Manufacturers lists three soft drink industries within Pima County. Each is primarily engaged in manufacturing soft drinks and carbonated waters. The significant operations with potential geothermal energy use are fructose storage, returnable bottle washing, can washing and clearup.

Presenty, natural gas is used for all of these operations with hot water as the medium. Fructose storage requires a process heat temperature of $32^{\circ} \mathrm{C}\left(90^{\circ} \mathrm{F}\right)$; bottle washing, $77^{\circ} \mathrm{C}-88^{\circ} \mathrm{C}\left(170^{\circ} \mathrm{F}-190^{\circ} \mathrm{F}\right)$; can washing, $54^{\circ} \mathrm{C}-60^{\circ} \mathrm{C}\left(130^{\circ} \mathrm{F}-140^{\circ} \mathrm{F}\right)$; and the clean-up operation, $60^{\circ} \mathrm{C}-77^{\circ} \mathrm{C}$ $\left(140^{\circ} \bar{E}-170^{\circ} \mathrm{F}\right)$. It is estimated that the bottle- and can-washing processes alone consume about $0.19 \times 10^{12}$ 3tu's/yr. Thus given the average assessed geothermal temperature in Pima County of $100^{\circ} \mathrm{C}\left(212^{\circ} \mathrm{F}\right)$, the above processes appear to be suicable for geocheral process hear applications. 


\section{Ready-Mix Concrete Industry (SIC 3273)}

There are three large firms within this industry in Pima County. Since the concrete is poured wet and is allowed to set at ambient temperature at the job site, energy consumption is for fuel for transportation rather than for process heat. Electricity is the prevailing energy source used in the crushing and mixing process so the low- to moderate-temperature geothermal resources of Pima County are not suitable for these applications. However, the ready-mix concrete industry does require large quantities of hot water for cleaning, wixing and storing. Geothermal energy potentially could be used to heat the water for these applications. SUMMARY

Work to date has concentrated on simple identification of potential users of geothermal energy. Specification of annual heating and cocling demands as well as further details on various industrial and agricultural heat requirements remains to be done. Such detail will better define the role which geothermal energy may play in future years. 


\section{Appendix A}

The New Mexico Energy Institute at New Mexico State University has developed a computer simulation mode1, BTHERM, to assess the economic feasibility of residential and comercial district space heating, hot water heating and industrial process heating using low temperature geothermal energy. Another model, CASH, was developed to depict the growth of geothermal energy on line over the next 40 years as a function of price of competing energy sources. A major assumption of these models is that geothermal energy must be price-competitive with the lowest-cost conventional energy source in order to assure market capture.

Development of a geothermal resource is characterized by large capital outlays, but a long-term geothermal investment has the potential to provide relatively inexpensive energy at a stable price. Unlike natural gas and electricity, however, geothermal energy is an unknown energy involving certain risks such as price and reservoir life and the need for back-up systems. An analysis of the costs and economic competitiveness of geothermal energy must take these uncertainties into account. Thus, costs may be overestimated so that the benefits will not be overstated.

The BTHERM computer simulation model models the residential, commercial and industrial sectors of a typical city, each sector having unique energy costs and energy system physical parameters as well as different growth rates. The model possesses the ability to model each sector individually and can analyze the application of geothermal energy to new growth only, to conversion of existing structures or to a combination of both. The model also has the capability to model both private and city-owned utility development of the geothermal resource. 
Output of the model includes the levelized price per million Btu of delivered energy, the discounted present value of investment necessary and the undiscounted values of investments for policy studies. Also, from input of the price and price growth rate of conventional energy, the model determines the discounted or undiscounted values for federal and state taxes, tax credits, royalty rates, property taxes and consumer savings due to conversion from conventional energy to geothermal. Certain limitations of the model have already been suggested. Costs, for example, may be overestimated due to safeguards built into the model to take into account the risks associated with geothermal energy. This overestimation of costs might result in the exclusion of a potential use of geothermal energy. Another limitation is that the price of natural gas is taken as the price of competitive (conventional) energy, but not all users have access to natural gas.

The output of the model is not a substitute for detailed engineering design studies but it is useful for determining order-of-magnitude costs and potential benefits of geothermal energy development. 
POTENTIAL USERS OF GEOTHERMAI ENERGY IN TUCSON

Type of Development

Hospitals

Air Force Base Hospital

Building 400

Davis Monthan AFB

Kino Community Hospital

2800 E. Ajo Road

Veterans Hospital

3601 S. 6th Avenue

\section{Eigh Schools}

Santa Rita High School

3951 S. Pantano Raod

Pueblo High School

3500 S. 12th Avenue

Sunnyside High School

1725 E. Bilby Road

\section{Shopping Centers}

Ajo Way \& S. 12th Avenue

W. Ajo Way \&. S. 12th Avenue

Grant Plaza South

S. Nogales tiwy. \& E. Drexel Road

Southgate

Interstate $10 \& S$. 6th Avenue

Irvington Plaza

E. Irvington Road \& S. Campbell Avenue

K-Mart on Valencia

Interstate $19 \& W$. Valencia Road 
Appendix B (continued)

Potential Users of Geothermal Energy in Tucson

Type of Development

Shopping Centers (continued)

Mission Manor

W. Valencia Road \& S. 12th Avenue

San Xavier Plaza

W. Ajo Way \& S. Mission Road

Major Industrial Parks

Broadbent Business Center

S. Palo Verde \& Veterans

Caylor Business \& Industrial Center

44 th Street \& Dodge BIvd.

Edelbrock Industrial Park

S. Park Avenue \& Evans Blvd.

Park Avenue Industrial Center

4690 S. Park Avenue

Tucson Business Park

Park Avenue \& Ajo Way

Tucson Industrial Center

Irvington Road \& S. 3rd Avenue

Papago-Tucson Foreign Trade Zone No. 48

Los Reales Road \& Old Nogales Hwy.

San Xavier Industrial Park

Los Reales Road \& Old Nogales Hwy.

Santa Cruz

West of Interstate 12 between

Irvington \& Valencia Roads

Tucson Aviation Center

7000 S. Nogales Hwy.

Tucson International Airport Industrial Park

7777 S. Nogales Hwy.

Valley Industrial Park No. 1

Country Club Road \& Valencia Road 
Appendix B (continued)

Potential Users of Geothermal Energy in Tucson

Type of Development

\section{Air Force Bases}

Davis Monthan Air Force Base

Industry

IBM

Interstate $10 \&$ Rita Road

Hughes Aircraft

Nogales llwy.

Newspapers

Arizona Daily Star/Tucson Citizen 4850 S. Park

\section{Airports}

Tucson International Airport

Valencia Road 


\section{BIBLIOGRAPHY}

References used in preparing the Area Development Plans

Arizona Agricultural Statistics 1978, 1979: Phoenix, Arizona, Arizona Crop and Livestock Reporting Service, 68 p.

Arizona Community Profiles, 1981: Phoenix, Arizona, Research Program, Arizona Office of Economic Planning and Development.

Arizona Statistical Review, 1979: Phoenix, Arizona, Valley National Bank of Arizona, 72 p.

Brown, R., 1978, Industrial Process Heat Demand Balance: Golden, Colorado, Solar Energy Research Institute, unpublished draft.

Climatograph of U.S. No. 81 Arizona, 1978: Asheville, North Carolina, National Climate Center.

Dunn, D. and Cox, D.C., 1979, Papers in Community Development No. 2 - SocioEconomic Indicators for Small Towns: Tucson, Arizona, Rural Information Center, 58 p.

Energy Analysis of 108 Industrial Processes, 1979: Philadelphia, Pennsylvania, Drexel University.

Energy-Saving Techniques for the Food Industry, 1977, M.E. Casper, editor: Park Ridge, New Jersey, Noyes Data Corporation, 657 p.

Frank, H.J., 1977, Arizona Energy Inventory: 1977: University of Arizona, Tucson, $100 \mathrm{p}$.

Gerber, L.A., Worden, M.A., and Dunn, D., 1980, Papers in Community Deve1opment No. 5 - Safford, Arizona: A Trade Area Analysis: Tucson, Arizona, Rural Information Center, $76 \mathrm{p}$.

Gibson, L.J., Worden, M.A., and Solot, M.S., 1979, Papers in Commuity Development No. 1 - A Citizen's Handbook for Evaluating Community Impacts: Tucson, Arizona, Rural Information Center, 65 p.

Hodgson, M.L., 1978, Arizona Job Scene 1985: A Labor Market Information Publication of the Arlzona Department of Economic Security, 133 p. 
Industrial Waste Heat Survey, 1978, Rocket Research Company.

Inside Phoenix 1979, 1979: Phoenix, Arizona, Phoenix Newspapers, Inc., 152 p.

Inside Phoenix 1981, 1981: Phoenix, Arizona, Phoenix Newspapers, Inc., 128 p.

1981 Directory of Arizona Manufacturers, 1981: Phoenix, Arizona, Phoenix Metropolitan Chamber of Commerce, 200 p.

Phase II - Arlzona State Water Plan: Alternative Future, 1977: Phoenix, Arizona, Arizona Water Commission, $145 \mathrm{p}$.

Population, Employment and Income Projections for Arizona Counties 1977 2000, July 1978 \& 1979: Arizona Department of Economic Security.

Population Estimates of Arizona as of July 1, 1979: Phoenix, Arizona, Arizona Department of Economic Security Report No. 12, 66 p.

Statistical Report for Financial Analysis 1969 - 1979: Phoentx, Arizona, Arizona Public Service Company, 24 p.

Stone, C., 1980, Preliminary Assessment of the Geothermal Potential at the Papago Farms, Papago Indian Reservation, Arizona: State of Arizona Bureau of Geology and Mineral Technology Open-File Report 80-6, 62 p.

Stone, C., 1981, A Preliminary Assessment of the Geothermal Resource Potential of the Yuma Area, Arizona: State of Arizona Bureau of Geology and Mineral Technology Open-File Report 81-4, 28 p.

Survey and Analysis of Solar Energy Process Heat Opportunities in Arizona, 1979: University of Arlzona, Department of Nuclear Energy, Energy Management and Policy Analysis Group, Final Report prepared for Arizona Solar Energy Research Commission under Office of Economic Planning and Development Contract No. 458-78

Swanberg, C.A., Morgan, P., Stoyer, C.H., and others, 1977, An Appraisal Study of the Geothemal Resources of Arizona and Adjacent Areas in New Mexico and Utah and Their Value for Desalination and other Uses: New Mexico Energy Institute Report No. 6, 76 p. 
Tucson Trends 1980, 1980: Tucson, Arizona, Valley National Bank of Arizona and Tucson Newspapers Inc., 88 p.

Witcher, J.C., 1979, Proven, Potential and Inferred Geothermal Resources of Arizona and Their Heat Contents: State of Arizona Bureau of Geology and Mineral Technology Open-File Report $795,65 \mathrm{p}$.

Witcher, J.C., 1981, Geothermal Energy Potential of the Lower San Francisco River Region, Arizona: U.S. Geological Survey Open-File Report 81-7, $135 \mathrm{pe}$ 